ROBERT MOWRIS PROFESSIONAL ENGINEER ENERGY CONSULTANT 205 Fairlawn Dribe, Berkeley, California 94708 (415) 549-2068

June 8, 1990

Dear Emmet,

I revised my study to answer criticisms from the Pro-geothermal Alliance, and to add the recent Electric Power Research Institute (EPRI) conservation supply curve to Figure 4. The following is a brief summary of answers to their "Mowris Study Flawed" flyer.

1. (4th paragraph-"Strawman" argument) Figure 2 has been revised to give the growth rate in electricity demand projected by HEOO. Also Figure 4 has been added to provide evidence for the rough estimate of 50\% savings. Note that the Electric Power Research Institute (EPRI) is currently estimating that total U.S. electricity savings of $40 \%$ are cost-effective at less than $3.5 \% / \mathrm{kWh}$. A more thorough study of Hawaii will provide even more proof for my assertion that at least $50 \%$ savings are possible (using projected demand for "energy services" in 2010). There was never any effort to create an artificial "stramman" argument. I just didn't have a realistic estimate of demand growth in my earlier studies.

2. (5th paragraph-Should $100 \%$ of the population pay for efficiency?) They are already paying for existing supply options, and will definitely pay for any new options such as $8 \mathrm{c} / \mathrm{kWh}$ (wholesale) ORMAT geothermal. Under a least-cost planning process, there are many ways for the utilities to get reimbursed for efficiency investments or rebates for efficient lights, appliances, solar water heaters, etc. I have discussed a simple way to do this in Section 6 and Table 2 of my revised report. It is always cheaper to buy efficiency, and as efficiency gets purchased some end-users will benefit more in the beginning than others. It is impossible to retrofit all houses and businesses at the same time. Improvements will take 10 to 20 years to implement. This underscores the importance of building standards to require all new houses and commercial buildings to use the most efficient technologies available (such as requiring solar water heaters on all new houses).

3. (6th paragraph) The reference to $40 \%$ of the state's power from bagasse has been eliminated. The sentence was only put in to show how inefficient current technologies are at converting bagasse into electricity. The new gasification/steam-injected gas turbine technology mentioned in Table 3 is in the R\&D phase and should be seriously examined by the state of Hawaii. DBED received a copy of the report that describes this new supply technology.

4. (7th paragraph) There are no errors in my calculation of the electricity generation potential from bagasse.

5. (8th paragraph) The land required by PV panels is not an issue. I mentioned in my earlier report that PV panels could easily be placed on roof tops. Once the most efficient lighting, appliances, etc. are installed in houses, and once we have cheap hydrogen fuel cells (or high efficiency batteries), we will be able to power homes with PV. Cully Judd and Lafayette Young (Maui) have already installed PV or wind systems on about 1,000 houses, but currently the cost is too high for most people. However, wind power is reasonable at about $1-1.5 \mathrm{c} / \mathrm{kW}$ installed. The extra cost is for battery storage is what gets expensive. In the next 5-10 years the cost is expecied to come down radically so that independent power for residential applications will be both cost effective and practical.

6. (9th paragraph) Hydrogen fuel cells and other storage technologies will be cost effective in 5 10 years and then solar and wind will be very good "baseload" providers of power. Why destroy 
the rainforest by building expensive geothermal ( $\$ 4000$ to $\$ 8000$ per $\mathrm{kW}$ ) when it isn't even a reliable "baseload" option.

7. (11th paragraph) The Geothermal Hotline didn't read my earlier report carefully. I never said that $50 \%$ of The Geysers was currently turned off. Only $20 \%$ is turned off, and $50 \%$ is projected to be turned off by the year 2000 .

8. (13th paragraph) My earlier studies had a few mistakes due to lack of information. The current version has been updated, and is being sent to Alan Lloyd for comments. I will continue to work to get the efficiency argument to the public. The study does contain valuable information regarding least-cost options and I hope it will be viewed as a solution by Hawaiian policy makers and planners.

I will be in Hawaii for the first IRP hearing on June 13th, and would be glad to answer any further questions regarding my revised study. Hope to see you at the first IRP hearing.

Sincerely,

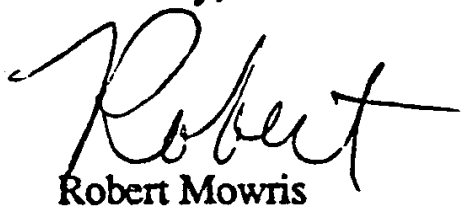




\title{
Energy Efficiency and Least-cost Planning: THE BEST WAY TO SAVE MONEY AND REDUCE ENERGY USE IN HAWAII
}

\author{
Robert J. Mowris, Professional Engineer \\ California License \#M 26191 \\ Energy Consultant \\ 205 Fairlawn Drive \\ Berkeley, California 94708
}

Draft

\author{
Revised ${ }^{\dagger}$
}

May 211990

\footnotetext{
TThis revision attempts to answer a critique provided by Alan Lloyd, Executive Engineer, Hawaiian Electric Company, and Geothermal Hotline, titled Mowris Study Flawed, April 1990, Progeothermal Alliance, 737 Bishop Street, Suite 2880, Honolulu, HI 96813. The previous April 4, 1990 revision resulted from information provided by the Governor's office and the Energy Division of the Hawaii Department of Business and Economic Development regarding efforts on the part of the Hawaii Public Utilities Commission to implement integrated resources planning. Additional information was also added on potential energy savings in Hawaii's transportation sector.

Note: This paper has become a forum for discussion regarding energy issues facing Hawaii, and will continue to be revised as more information becomes available. Comments or criticisms are welcome.
} 


\section{Abstract}

If the $500 \mathrm{MW}$ geothermal project on the Big Island of Hawaii is developed as planned, the Wao Kele 'O Puna rainforest will be severely damaged or destroyed. If this happens the State will lose one of its most precious resources. It would be tragic for this to happen, since on a least-cost basis, the geothermal project does not make economic sense. Improving energy efficiency in the commercial and residential sectors of Hawaii can save about $500 \mathrm{MW}$ of power at a cost of $\$ 700$ million. This is about 5 or 6 times less than the $\$ 3.4-4.6$ billion cost for the proposed $500 \mathrm{MW}$ geothermal project and accompanying undersea cable. Over the next 20 years, improved efficiency could reduce electricity demand in Hawaii by about $50 \%$ at an average cost of about $4 \mathrm{c/kWh}$. The "bottom line" is that the geothermal project is risky, expensive to build and maintain, and comes with no guarantees. On the other hand, a statewide energy efficiency program, using proven technology, will free up more power than the geothermal project could ever provide, will save Hawaiian ratepayers hundreds of millions of dollars, and will buy precious time to develop other less costly renewable options such as solar and wind power.

A good analogy for Hawaii's current energy situation is a wooden tub with millions of leaks. More leaks develop every day as developers build inefficient buildings on speculation. From the utilities perspective putting in another hose and pumping in more power looks like the most obvious answer to keep the wooden tub full. However, a more intelligent and far less costly solution is to $\mathrm{r}$. 0 ull of the millions and millions of leaks with reliable and readily available energy efficient technologies, and establish strong building standards to prevent more leaks from developing. If this path is followed not only will no new supply be needed over the next 10-20 years, but some of the existing supply can be turned off.

The choice is simple, improving electricity efficiency is much more cost-effective than developing any new supply options. Now that Hawaii has embarked on an integrated resources planning process this fact will be brought to light. Integrated resources planning will hopefully provide a framework to compare all available resource options, including energy efficiency improvements, on a level playing field. All available resource options must be seriously evaluated on an economic basis before plans for the geothermal project go any further.

\section{Acknowledgements}

I would like to thank Dr. Arthur Rosenfeld, Director of the Center for Building Science, at Lawrence Berkeley Laboratory for valuable comments and suggestions. I would also like to express my appreciation to the Rainforest Action Network for providing limited funding for the first and second drafts of the study, and Jennifer Stout who also provided financial support for the study and originally inspired me to get involved with this issue. 


\section{Introduction}

THE GOOD NEWS is that improving energy efficiency in buildings, industry, and transportation is the most cost-effective way for Hawaii to reduce its dependence on oil imports. Sensible investments in energy efficiency can reduce electricity use in Hawaii by about $50 \%$ and reduce oil imports by about $30 \%$. The technologies to achieve these savings are already available-such as more energy-efficient lights, windows, appliances, motors, cars, and jets-but building energy standards, an aggressive retrofit program, and economic incentives are needed to get these products into the market place. The State of Hawaii is now in the process of adopting Integrated Resources Planning (IRP) to ensure that utilities identify all available cost-effective options for meeting new electricity demand before making any investments in more expensive new supply. The State is also in the process of adopting commercial and residential building standards. These programs and standards will help Hawaii realize substantial energy savings.

Figure 1 shows that compared to pre-1973 efficiency levels, Hawaii saved about 50 trillion Btu in 1986-equivalent to 8.5 million barrels of oil worth $\$ 250$ million. ${ }^{1}$ Similarly, Figure 2 shows that compared to pre-1973 trends, Hawaii saved 3 billion kilowatt-hours (BkWh) of electricity in 1986. The future challenge facing Hawaii is shown in the right-hand wedge of Figure 2. Hawaiian Electric Company is projecting a 2.6\%/year growth rate in total statewide electricity use, a $70 \%$ increase in demand compared to current levels. ${ }^{2}$ The really good news is that it is technically possible and economically justifiable to achieve a $2.6 \%$ /year growth rate in "energy services" and yet still reduce electricity demand by $50 \%$ through improved efficiency. Doing this will save Hawaiian ratepayers \$3.4 billion over the 20-year period from 1991 to 2010. By adopting progressive policies to promote efficiency, Hawaii can keep demand low, and buy precious time to develop cost-effective renewable energy options like solar and wind power.

THE BAD NEWS is that after world oil prices fell in late 1985, Hawaii temporarily lost its focus on energy efficiency. Figure 1 shows that energy use is once again in lock-step with economic growth. Oil imports are growing, and "friendly" oil reserves in the U.S. are dwindling. Developers in Hawaii are constructing suboptimal buildings and that will require expensive energy during most of their 75-100 year lifetimes. New cars and appliances imported to Hawaii are suboptimal even at today's low energy prices. Behind this bad news is the long-standing tradition that individual, industrial, and government planning horizons for efficiency investments are usually three years or less. This is true for an individual buying an appliance or car, an airline company investing in new jets, or a developer building a hotel. Conversely, for supply side investments (oil wells or power plants) we often tie up our money for more than 10 years. This "tilted" playing

\footnotetext{
${ }^{1}$ Savings based on the current average U.S. price of $\$ 5 /$ million Btu. The total U.S. energy bill is $\$ 400$ billion for 80 quadrillion Bu, Monthly Energy Review, April 1989, Energy Information Agency.

2Personnal communication, Alan Lloyd, Hawaiian Electric Company (see footnote in Figure 2 for more detail).
} 
field has led to an over-investment in energy supply relative to efficiency. The result is a net annual energy bill which is about $30 \%$ larger than it should be, and fuel consumption and pollution nearly $50 \%$ greater than the economic optimum.

THE REALLY BAD NEWS is that Hawaii is on the verge of developing an expensive 500 megawatt (MW) geothermal project on the Big Island of Hawaii. Early estimates of the cost for the proposed $500 . \mathrm{MW}$ geothermal project were about $\$ 600-900$ million, with the accompanying undersea cable adding another $\$ 300-500$ million, making the total cost about $\$ 1-1.4$ billion. Recent estimates place the cost at $\$ 3.4-4.6$ billion, more than twice the early estimate. ${ }^{3}$ There is a risk involved, since the geothermal resource under the east rift of Kilauea could be depleted if anything in excess of $5 \mathrm{MW}$ of electrical power is extracted. ${ }^{4}$ If the project continues as planned, the delicate Wao Kele 'O Puna rainforest will be severely damaged or destroyed. ${ }^{5}$ This will seriously impact U.S. efforts to halt rainforest destruction worldwide.

\section{Energy Efficiency and Least-Cost Planning.}

To realize the potential 50\% reduction in electricity use shown in Figure 2 Hawaii must redefine its energy policy, by first of all redefining the very concept of energy. We use energy as a means to an end, not an end in itself. People aren't interested in kilowatt-hours of electricity or barrels of oil, they want the energy services that electricity and oil provide, such as: comfortable housing, quality lighting, convenient transportation, or a cold drink on a hot day. Providing the same or better quality energy services tnrough improved energy efficiency, is the key to reducing energy demand. It is much cheaper and easier to reduce energy demand through improved efficiency, than it is to develop expensive energy supply options, even if the supply options are renewable. Appendix A gives an example of a large-scale conservation program initiated by the New England Electric System (NEES). NEES will spend $\$ 65$ million per year (4\% of its revenues), and hopes to meet $35-57 \%$ of its total electricity needs for the next 20 years through currently available efficiency improvements, while maintaining or increasing the six-state region's

\footnotetext{
${ }^{3}$ Economic Analysis of the Kilauea Geothermal Development and Inter-Island Cable Project, Dr. Robert McKusick and Richard Topielec, Northwest Economic Associates, 13101 N.E. Highway 99, Suite 200, Vancouver, WA 98686-2786.

${ }^{4}$ Testimony of Robert W. Decker, Scientist-in-Charge, U.S. Geological Survey, Hawaiian Volcano Observatory.

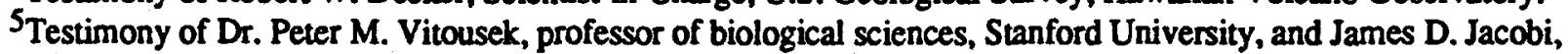
botanist, U.S. Fish and Wildlife Service, Patuxent Wildlife Research Center (Endangered Species Branch), presented in United States District Court for the District of Hawaii, Civil No. 88-00320, June 23, 1989. Both Vitousek and Jacobi stated that the Wao Kele 'O Puna and the Puna Forest Reserve Lands contain lowland rainforest vegetation dominated by indigenous, native species of plants and are relatively free from introduced species. Approximately 90\% of Wao Kele 'O Puna and $80 \%$ of the Puna Forest Reserve Lands fall within this classification (Jacobi). Nowhere else on earth is there such a spectacular matrix of climate and soils occupied by plants and animals whose evolutionary history is known (Vitousek). Clearing of native forest habitats for roads and work sites will lead to accelerated dispersal of introduced non-native plants. Once established, aggressive non-native plants exclude native plants by competing for both light and nutrients, upsetting the natural balance in the native plant communities, resulting in irreversible degradation of the lowland rainforest community.
} 
current rate of economic growth. For comparison, Hawaii is only spending about $\$ 2$ million per year on energy conservation, and this is only $0.3 \%$ of total Hawaii electric utility revenues.

A serious statewide energy conservation program involves much more than educational efforts and energy audit programs. Hawaii needs building energy standards, financial incentives, and rebate programs to encourage consumers to invest in energy efficiency. Utility profit-making rules have to be rewritten to reward utilities for investing in the energy efficiency of their customers. Additionally, a least-cost planning policy must be adopted to ensure all available options for meeting new electricity demand are assessed before investing in new supply.

At least 17 states have adopted least-cost planning strategies, and 8 other states are now in the process of evaluating least-cost planning guidelines. A least-cost planning policy must contain the following three aspects (Appendix B provides a detailed outline):

1) Planning: each utility submits a least-cost resource plan. Utilities are required to submit a longrange (10 to 20 year resource plan every two years to the state regulatory commission. The plan must include a forecast of future demand, an assessment and integration of demand-side and supply-side resource options, an implementation plan, and a non-technical summary to help facilitate public participation.

2) Evaluation: state reviews utility plans. Guidelines are established and a statewide electrical energy plan must be developed to help evaluate utility plans. The state must provide for public participation in the resource olanning .

3) Enforcement: effective control over utility investments. The state commission must have the authority to approve or reject utilities' long-range resource plan. A certificate of public need incorporating demand and supply-side options must be obtained before authorizing the siting or construction of new power plants. Additionally, the commission must have the authority to require utility conservation programs, and must encourage the development of alternative resources from small power producers (such as renewable and cogeneration).

\section{California: An Example for Hawaii.}

Hawaii could leam much from Califomia, where building and appliance standards, utility programs, and market impacts have already saved ratepayers billions of dollars and helped Califomia avoid building $10 \mathrm{GW}$ of additional generating capacity. ${ }^{6}$ California's appliance standards became the role model for the National Appliance Standards ${ }^{7}$ that will result in savings of $44 \mathrm{BkWh}$ and $13 \mathrm{GW}$ of capacity nationwide by the year 2000.8 Figure 3 shows that

\footnotetext{
${ }^{6}$ Savings from 1977 to 1988 are 30 BkWh and 246 trillion Btw, pp. 22,23, Conservation Report, Califomia Energy Commission, October 1988, P400-88-004.

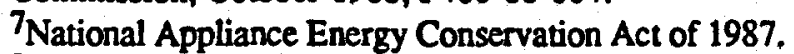

8 Impacts of Federal Efficiency Standards for Residential Appliances, H. Ruderman, M. Levine, J. McMahon, I. Turiel, S. Stoft, Lawrence Berkeley Laboratory, Draft Report, 1988, and Howard Geller, American Council for an Energy-Efficient Economy, 1988.
} 
California's progressive energy policies reduced per capita electricity use by $3.4 \%$ from 1978 to 1988, while over the same period per capita energy use in Hawaii increased 10\%.9 Californians now use $20 \%$ less energy per dollar of Gross State Product (GSP) than Hawaiians.

\section{The California Energy Commission}

Much of California's success is due to the establishment of the California Energy Commission (CEC) in 1977. Besides writing and revising California's building and appliance standards, the CEC is also charged with:

1) Submitting a biennial conservation report to the Governor and Legislature. The purpose of the report is to identify trends in the residential, commercial, industrial, agricultural, and transportation sectors; specify conservation reasonably expected to occur over the forecast period; indicate the potential for additional conservation, identify improvements to existing programs; and recommend legislative or administrative actions, programs, and policies.

2) Forecasting energy demand and supply for each utility in the state,

3) Defining and directing innovative resource projects related to both demand and supply, and

4) Approving or denying the need for new power plants, and if needed siting power plants, to ensure valuable ecological areas are protected from development.

These tasks are all open to public comment and debate.

Hawaii should follow California's example and establish an energy commission as a separate state government agency. A Hawaii Energy Commussion will help promote energy conservation and assure the state meets future energy needs.

\section{Geothermal Is Risky and Expensive.}

The world's largest geothermal-power field, The Geysers located in Northern California, is running out of steam. Steam pressure at The Geysers has already dropped by $20 \%$, and predictions are that it will drop below $50 \%$ over the next 10 years. ${ }^{10}$ In the early 1970 s it was thought that The Geysers could support 3,000 MW of power, and by 1987 about 2,000 MW were installed. Now $400 \mathrm{MW}$ of capacity is standing idle. More steam is being removed than can be replaced by the hot underground magma.

Of course there is no way to compare California's Geysers with the east rift of Kilauea, but there is evidence to suggest that the long-term geothermal electrical capacity on the Big Island is much less than the $500 \mathrm{MW}$ targeted for development. According to testimony given in 1982 by

\footnotetext{
${ }^{9}$ Including the impact of Hawaii's large visitor industry yields a 7\% increase in de facto per capita electricity use over the ten year period from 1978 to 1988.

${ }^{10}$ Claudia Barker, Information Officer, Califomia Energy Commission, see Geysers Failing: Billions of Dollars May Be Lost, Oakland Sunday Tribune cover story, pages A1, A14, November 5, 1989.
} 
Robert Decker, Scientist-in-Charge , U.S. Geological Survey's Hawaiian Volcano Observatory,

[A]ny electrical power extraction from the Kahaule'a section of the east rift of Kilauea in excess of about $5 \mathrm{MW}$ will not be [sic] replenished by new thermal power from the volcano ...[and] will probably deplete [sic] the geothermal resource.

Installing $500 \mathrm{MW}$ of capacity when the east rift of Kilauea might only support about $5 \mathrm{MW}$ is a big gamble.

Geothermal power is also expensive. A recent study completed by the California Energy Commission estimated the nominal 30-year levelized cost of geothermal power to be $12 \mathrm{k} / \mathrm{kWh}$ (in \$1987). ${ }^{11}$ The constant dollar cost is about $6 ₫ / \mathrm{kWh} .12$ The cost for geothermal power from the $25 \mathrm{MW}$ Ormat project is about $8 \mathrm{k} / \mathrm{kWh}$. Adding in the cost of the undersea cable to deliver the power to Maui and Oahu brings the wholesale cost to about $10 \mathrm{c} / \mathrm{kWh}^{13}$ (assuming the cost per kilowatt-hour for the $500 \mathrm{MW}$ project is about the same as the cost for the Ormat project). Adding another $3 \notin / \mathrm{kWh}$ (U.S. average retail markup) to the constant dollar cost yields an average retail price of about $13 \mathrm{k} / \mathrm{kWh}$ (see Table 2 far right-hand column). The high cost of $15.5 \mathrm{k} / \mathrm{kWh}$ is based on a recent study by the Northwest Economic Associates. Why should Hawaiian ratepayers be forced to pay 13-16 $\mathrm{k} / \mathrm{kWh}$ for $500 \mathrm{MW}$ of geothermal electricity, or any new supply option, when improving electricity efficiency is far more cost effective?

\section{Improving Energy Efficiency is the - at Choice for Hawaii.}

A typical utility incentive program to reduce electricity demand by $30-40 \%$ will cost less than $4 \mathrm{k} / \mathrm{kWh}$. Effective building standards and aggressive demand-side management programs programs could easily create statewide savings of $40-60 \%, 14$ and the technical potential is even greater. Figure 4 shows a collection of efficiency supply curves illustrating the maximum technical potential for electricity savings in the United States. The supply curves indicate that for an average cost of less than $2 \mathrm{c/kWh}$ it is technically possible to save $40-75 \%$ of annual electricity use within the United States. The mid-range of these estimates is $60 \%$. Therefore, setting a goal to achieve a $50 \%$ reduction in total electricity use in Hawaii by the year 2010 (as shown in Figure 2) is not unrealistic. Table 1 and Figure 5 show the estimated savings that Hawaii could expect

\footnotetext{
11 Energy Technologies Status Report, CEC, P500-88-003D, Appendix D, Detailed Economic Analysis. Data given in Appendix C for Geothermal Dry Steam shows $11.4 \mathrm{f} / \mathrm{kWh}(\$ 1985)$. Converting to $\$ 1987$ yields $12 \mathrm{c} / \mathrm{kWh}$.

${ }^{12}$ Gerry Bemis et al, Energy Technology Status Report Number 2, in preparation, available May 1990.

${ }^{13}$ The undersea cable would add $\$ 300-500$ million to the capital cost of developing the geothermal resource. This adds 3-5 $\mathrm{k} / \mathrm{kWh}$ or about $4 \mathrm{k} / \mathrm{kWh}$ to the 30-year levelized nominal cost of the geothermal project or $2 ₫ / \mathrm{kWh}$ to the constant dollar cost (based on adding $\$ 600-1000 / \mathrm{kW}$ to the $500 \mathrm{MW}$ base year capital cost of $\$ 1797 / \mathrm{kW}$, see Geothermal Dry Steam spreadsheet in Appendix C).

${ }^{14}$ See Power By Design. New England Electric System and the Conservation Law Foundation and Analysis of Michigan's Demand-Side Electricity Resources in the Residential Sector, LBL Report 23025, February 1987, Lawrence Berkeley Laboratory, Berkeley, CA 94720 (also see Appendix A).
} 
from a statewide residential electricity-efficiency program. ${ }^{15}$ Figure 5 shows that total residential demand could be reduced by about $66 \%$ (1,360 million $\mathrm{kWh})$, at an average cost of $3.6 \notin / \mathrm{kWh}$. Similar savings are possible in the commercial sector. Lighting, alone accounts directly for $33 \%$ of commercial electricity demand 16 , and indirectly for an additional $10 \%$ due to cooling energy that is needed to remove the heat generated by lighting. 17 It is both technically possible and economically justifiable to save $60-90 \%$ of the energy currently used for lighting at a cost of less than $1 \mathrm{c/kWh}$ using better lamps, electronic ballasts, specular reflectors, and lighting controls. ${ }^{18}$ Assuming energy used directly by lighting can be reduced by $70 \%$ yields a demand reduction of almost 1 $\mathrm{BkWh} /$ year. Adding in the cooling bonus yields an additional $0.4 \mathrm{BkWh}$ of savings for a total annual demand reduction of $1.4 \mathrm{BkWh}$.

Investing about $\$ 100^{19}$ million to improve commercial lighting efficiency in Hawaii could save about $245 \mathrm{MW}$ of existing capacity. ${ }^{20}$ Investing an additional $\$ 600$ million to reduce residential energy use (Table 1) could save an additional $240 \mathrm{MW}$ of capacity. ${ }^{21}$ The total estimated cost to buy $485 \mathrm{MW}$ is about $\$ 700$ million dollars. The cost per MW to implement these efficiency improvements is about 4.8-6.5 times less than the \$3.4-4.6 billion cost of the proposed $500 \mathrm{MW}$ geothermal project and accompanying undersea cable.

Many supporters of geothermal development seem to be ignoring the costs, and are saying that buying new supply and efficiency at the same time is the best way to go, that utilities should do both: If the state pursues both it may end up getting neither. New supply and imnroved efficiency compete for the same financial resources, skills, and attention. To pay for new supply

\footnotetext{
${ }^{15}$ Based on rough estimates of residential electricity end-use of $40 \%$ electric hot water, $20 \%$ refrigerator, $8 \%$ lighting out of 1988 total residential use of $2.045 \mathrm{BkWh}$ (data from Hawaii Dept. of Business and Economic Development).

${ }^{16}$ Estimated by Lynn Zane, Statistician, Department of Business and Economic Development. Out of total nongovernment electricity use, commercial lighting represents about $0.33 \times 2.4 \mathrm{BkWh}=0.792 \mathrm{BkWh}$. Excluding military use, this is about $18 \%$ of total Oahu electricity demand. Assuming this percentage applies to the rest of the state yields $0.18 \times 7.7=1.4 \mathrm{BkWh}$ for total statewide commercial lighting.

${ }^{17}$ Every unit of energy saved in lighting saves an additonal 35-50\% in cooling energy (see State of the Art: Lighting, A. B. Lovins, R. Sardinsky, P. Kieman, T. Flanigan, B. Bancroft, J. Neymark, Competitek, page 16, March 1988). In Hawaii the savings is probably closer to $40 \%$.

${ }^{18}$ See Initiating Least-Cost Planning in California: Preliminary Methodology and Analysis, D. Goldstein, R. Mowris, B. Davis, K, Dolan, Natural Resources Defense Council and Sierra Club, prepared for the State of California Energy Resources Conservation and Development Commission, Docket No. 88-ER-8, February 21 , 1990, and State of the Art: Lighting, A. B. Lovins et al, Competitek, March 1988.

${ }^{19}$ Assuming 0.7 BkWh can be obtained for a Cost of Conserved Energy (CCE) of $0.8 \notin / k W h$. Dividing by the capital recovery factor (CRF) of 0.08 (using a 20 -year life and 5\% real discount rate) gives a cost of $\$ 0.104 / \mathrm{kWh}$ and multiplying by the $1 \mathrm{BkWh}$ of direct savings yields a one time cost of $\$ 100$ million. (For more detail on how to calculate the CRF see the bottom of Table 1.)

${ }^{20}$ Assuming a $65 \%$ capacity factor.

${ }^{21}$ Assuming all of the showerhead, refrigerator, compact fluorescent lamp, and solar water heater measures are implemented. Note that this cost is extremely conservative since many other more economically attractive options in the commercial and industrial sectors haven't been considered due to time constraints. In this example, the high cost for purchasing $240 \mathrm{MW}$ of residential savings reflects the fact that in order to obtain $100 \%$ penetration consumers are either given large rebates or the efficient products are simply given away free (i.e. utilities actually purchase the products and provide them at no cost to their residential customers). It is important to also note that this is currently being done by utilities in Maine, Iowa, Wisconsin, and California.
} 
more demand is needed, not less. As energy prices increase and more cost-effective efficiency options become available, customers will sooner or later buy more efficiency and less energy. The wise utility will sell customers what they want, before someone else does. Hawaiian electric utilities must become active participants in the efficiency revolution or face obsolescence.22

\section{How Can Utilities Profit From Investing In Efficiency?}

Table 2 shows a very simple example of how Hawaiian utilities can profit from demandside management (DSM) programs to improve the efficiency of their customers. The basis for Table 2 is the right-hand wedge of savings shown in Figure 2 (the goal of a 50\% reduction in total electricity demand by the year 2010). According to this example Hawaiian utilities would spend about $\$ 85$ million per year on DSM (Column $A+B+C$ ), receiving $\$ 7.5$ million/year in profit (a $10 \%$ rate of return - Column B) plus $\$ 2.6$ million/year for taxes (Column C). Following this approach would reduce demand by about 315 million $\mathrm{kWh} / \mathrm{year}$. The ratepayers would have to pay an additional average statewide DSM charge of 1.1-1.3 $\mathrm{c} / \mathrm{kWh}$ over the 20-year period to pay back the utilities' DSM investment. Although there might be some opposition to this DSM charge, the alternative of adding expensive new supply to meet increased demand, without a DSM program, would definitely raise electricity rates more than the DSM charge. Everyone would benefit from the installation of more efficient lighting, appliances, and solar water heaters, and average monthly bills would decline by $44 \% .23$ The total cost to the ratepayers for such savings would be about $\$ 1.7$ billion dollars, but the net savings to ratepayers would be $\$ 3.4$ billion. ${ }^{24}$

The remarkable savings shown in Table 2 point to the need to rewrite utility profit-making rules to decouple net revenues from total projected sales so that utilities can profit from investments in efficiency. California utilities have already done this through the Electric Rate Adjustment Mechanism (ERAM). ${ }^{25}$ ERAM ensures that a utility will fully collect authorized revenue requirements irrespective of the level of sales. Over or undercollections of revenues accrue to a balancing account and are amortized into future rates. This mechanism protects utilities from the risk of sales deviating from expectations, and allows the utilities to profit from efficiency investments.

\footnotetext{
${ }^{22}$ Most of the preceeding paragraph was paraphrased from a luncheon speech given by Amory Lovins at the Enhancing Renewable Energy Development in Hawaii (EREDH) Workshop, sponsored by the State of Hawaii and the Department of Business and Economic Development Energy Division, Sheraton-Waikiki Hotel, Honolulu, Hawaii, July $26 \& 27,1989$.

$23_{1} \cdot(0.5 \times 1.12)=0.44$.

${ }^{24}$ Based on the sum of annual statewide savings from DSM-65 BkWh $X(9.4-4.2=5.2 \mathrm{~d} / \mathrm{kWh}$ ) $=\$ 3.4 \mathrm{~B}$ (see footnote, Figure 2).

25For a detailed examination of ERAM see Ratemaking for Conservation: The California ERAM Experience, C. Marnay, G. Comnes, LBL-28019, Lawrence Berkeley Laboratory, March 1990.
} 


\section{What Other Renewable Options Are Available?}

Only after all cost-effective demand-side options have been exhausted, should utilities seek new energy supply. If new supply is necessary, then geothermal must be scrutinized along with all other new resources such as biomass, solar, and wind power. A comparison of these alternatives is given in Table 3. The far right-hand column gives the 30-year levelized retail cost; including transmission, distribution, capital, operating and maintenance, consumables, insurance, and financial costs. Biomass, solar-thermal, wind, and solar photovoltaic-concentrating power are all more cost-effective than the Ormat geothermal power project. All of the alternative renewable resources listed in Table 3 are cheaper than the $500 \mathrm{MW}$ geothermal project and accompanying undersea cable. ${ }^{26}$

The least-cost supply option is improving the efficiency of sugar cane processing and cogeneration. In 1988, Hawaiian sugar cane mills provided over 450 million $\mathrm{kWh}$ for sale to Hawaiian electricity users, about $6 \%$ of total Hawaiian electricity use. 27 If Hawaiian sugar cane producers improve cane processing efficiency ${ }^{28}$ and combine this with biomass gasification and steam-injected gas turbines ${ }^{29}$ for cogeneration, they could provide much more electricity. Sugar cane harvested on the Big Island alone could have produced 900 million $\mathrm{kWh}$ (180 MW) or 4 times more than was actually produced in 1988. As shown in Table 3, the cost of this technology is $45 \%$ less than the cost of the proposed $500 \mathrm{MW}$ geothermal project and accompanying undersea cable. Government or private financial support from outside the sugar cane industry is needed to help demonstrate this new technology. With government support, commercial systems should be available in about $3-5$ years. ${ }^{30}$

The issue of concern for biomass and solar is how much land area is required (wind isn't really an issue since the land under wind turbines can le used for pasture or agriculture). Table 3 gives estimates of land area required per $100 \mathrm{MW}$ of power production. Solar-thermal requires only 2.5 times more land area than geothermal. Photovoltaics require about 4 times more land than geothermal, but can eventually be placed on rooftops. Land area required for biomass assumes

\footnotetext{
${ }^{26}$ Assuming the undersea cable adds an average of $2 \mathrm{k} / \mathrm{kWh}$ to the 30 -year levelized cost of the Hawaii geothermal project. This cost could be higher or slightly lower, but is a reasonable estimate.

27 Personal communication, William Keenliside, Hawaiian Sugar, (808) 487-5561.

${ }^{28}$ By switching to falling-film evaporators rather the old rising-film technique to evaporate cane juice into sugar, see Process Energy Efficiency and Cogeneration in Cane Sugar Factories, J.M. Ogden, S. Hochgreb, M. Hylton, Proceedings of 20th Congress of International Society of Sugar Cane Technologists, Sao Paulo, Brazil, 1989. ${ }^{29}$ Biomass gasification with steam-injected gas turbines can produce about $450 \mathrm{kWh} /$ tonne of cane (includes bagasse and some tops and leaves of cane), with $25 \mathrm{kWh} /$ tonne going to processing, yielding $425 \mathrm{kWh} /$ tonne for sale to Hawaiian electricity customers. In 1988, 7 million tonnes of sugar cane was produced, and this much cane could have provided 3 billion $\mathrm{kWh}$ of electricity to Hawaiian electricity users, almost 7 times more than the 450 million $\mathrm{kWh}$ produced in 1988.

30For more on gasification and hot gas cleanup systems for use with steam-injection gas turbines, see Biomass Gasification for Gas Turbine Power Generation, Eric Larson, Per Svenningsson, Ingemar Bjerle, pp. 697-739, Electricity: Efficient End-Use and New Generation Technologies and Their Planning Implications, T. Johansson, B. Bodlund, R. Williams, Editors, ISBN 91-7966-065-7, Lund University Press, Lund, Sweden, 1989.
} 
sugar cane waste as a feedstock, so this isn't a problem, except for Oahu, where land is in short supply.

Table 3 shows that the lead time required for solar and wind power is small, 1.5-3 years, compared to 6 years for geothermal. These lead times are based on regulatory constraints in California which are much tougher than Hawaii. In Nevada, a solar-thermal power plant can be built in less than a year, according to Luz, the world's leading manufacturer of commercial solar electric power plants. Luz is currently producing nearly $200 \mathrm{MW}$ of electricity for Southern Califomia Edison (SCE), and recently began building another $400 \mathrm{MW}$ of capacity for SCE. When completed, Luz's production of solar electricity will total almost $600 \mathrm{MW}$, enough electricity to serve the residential needs of over 800,000 people, as many people as live in Honolulu. ${ }^{31}$ Solar and wind power are cheaper than geothermal, and should be given a high priority in any discussion of new power resources for Hawaii. Of course, this is only after all cost-effective energyefficiency measures have been implemented.

\section{What About Transportation?}

Jet fuel is the biggest user of oil in Hawaii. In 1987 jet fuel accounted for $42 \%$ of total oil use in Hawaii compared to $34 \%$ for electricity use. Hawaii could save a lot of oil if the fuelefficiency of commercial airliners could be improved. A new airliner developed by McDonnell Douglas, the MD-91/92, saves about 50\% in jet fuel compared to typical jet aircraft, meets or exceeds all current or anticipated noise rules, and has the quietest interior of any commercial airliner. ${ }^{32}$ Emissions of unburned hydrocarbons, carbon monoxide, and nitrogen oxides are also much lower than the current standard-body fleet average. ${ }^{33}$ Despite a very successful demonstration program of two engine types and a year-long marketing effort, no commercial airline company was willing to commit to this new aircraft, and consequently McDonnell Douglas decided to abandon further marketing efforts as of the summer of 1989. In order to reduce jet fuel use and pollution, the State of Hawaii must encourage Hawaiian Airlines, and other commercial airline companies serving the Hawaiian Islands, to purchase the most efficient airliners possible. Hawaii must join with other states to push for higher efficiency levels for commercial airliners.

Motor gasoline use accounts for about $20 \%$ of total oil use in Hawaii. Improving the fuel efficiency of new cars is possible through the use of better engine design, new transmissions, front-wheel drive, aerodynamics, and lighter materials. The average fuel efficiency of new cars sold in 1988 was $28.2 \mathrm{mpg}$, slightly better than the corporate average fuel economy (CAFE)

\footnotetext{
${ }^{31}$ The Luz solar-thermal technology in Califormia runs on solar 33\% of the time and fossil fuel $67 \%$ of the time. 32P. A. Henne, MD-90 Transport Aircraft Design, Douglas Aircraft Company, McDonnell Douglas Corporation, Long Beach, CA, presented at the American Institute of Aeronautics and Astonautics AIAA/AHS/ASEE Aircraft Design, Systems and Operations Conference, Seattle, WA, July 31-August 2, 1989.

${ }^{33}$ The HC reductions are $87 \%$, CO reductions are $57 \%$, and NOX reductions are $24 \%$ (refer to Henne).
} 
standards of 27.5 mpg. ${ }^{34}$ In 1988, new car sales records show that almost $40 \%$ of new cars sold in the U.S. had average fuel economies greater than 30 miles per gallon ( $\mathrm{mpg}$ ). ${ }^{35}$ One-quarter of these had fuel economies greater than $35 \mathrm{mpg}$. It is both technically possible and economically justifiable to improve the average fuel economy of new cars to $38-40 \mathrm{mpg}$ without changing the market mix of small, medium, and large cars sold. ${ }^{36}$ Hawaii could push for higher fuel efficiency by adopting legislation that ties the fuel efficiency of new cars to their registration fee. Such a program is currently being considered in California ${ }^{37}$, and could easily be adopted by Hawaii to reduce motor gasoline use. Besides developing a state incentive program, Hawaii must join with other states in pushing for higher CAFE standards. The federal CAFE standards have been stalled at or below $27.5 \mathrm{mpg}$ for almost 5 years, and it is time to move forward and raise the level of new car fuel efficiency nationwide.

The state is currently considering mass transportation options for Honolulu, and the county councils on Maui and Kauai are also examining alternative mass transportation systems. Light rail or MAGLEV trains connecting airports to hotels and major cities would drastically cut rental car congestion, and save thousands of barrels of oil per day. Another transportation mode that is largely overlooked is the bicycle. Counties could easily build bicycle lanes along major highway corridors, and provide regular bus sevice with racks for bikes. This would get people out of their cars, and provide a unique tourist attraction. Bicycles combined with light rail or buses with bike racks would be a very energy efficient alternative to automobiles.

\section{Recent Efforts By Hawaii to Implement Least-Cost Planning.}

In September of 1989 the Hawaii Integrated Energy Policy Development (HEP) program was officially launched, marking what promises to be the beginning of a least-cost planning process in Hawaii. The HEP program is the first step towards assessing demand and supply-side resources on an equal basis. As part of the HEP program the Hawaii Public Utilities Commission (HPUC) issued Order Number 10458 to develop an Integrated Resources Planning (IRP) process. This process is crucial to developing and defining the methodology used in this and all future leastcost planning processes. Governor Waihee is also introducing legislation to mandate demand-side management, and is supporting an increase of State tax credits for solar and energy efficiency technologies. These programs and standards promise a new age of enlightened energy policy for Hawaii.

\footnotetext{
${ }^{34}$ Patricia S. Hu, L.S. Williams, D. J. Beal, Light-Duty Vehicle MPG and Market Shares Report: Model Year 1988, page 2-1, ORNL-6549, Oak Ridge National Laboratory, Oak Ridge, TN 37831, April 1989.

${ }^{35} \mathrm{Hu}$ et al, 1989, pages 2-34 through 2-36.

${ }^{36} \mathrm{C}$. Difiglio, K. Duleep, D. Greene, Cost Effectiveness of Future Fuel Economy Improvements, The Energy Journal, January 1989.

${ }^{37}$ D. Gordon, L. Levinson, Drivet: A Proposal for California to Use Consumer Fees and Rebates to Reduce New Motor Vehicle Emissions and Fuel Consumption, prepared for U.S. Environmental Protection Agency, July 1989.
} 


\section{Conclusion.}

If the $500 \mathrm{MW}$ geothermal project on the Big Island of Hawaii is developed as planned, the Wao Kele 'O Puna rainforest will be severely damaged or destroyed. If this happens the State will lose one of its most precious resources. It would be tragic for this to happen, since on a least-cost basis, the geothermal project does not make economic sense. Improving energy efficiency in the commercial and residential sectors of Hawaii can save about $500 \mathrm{MW}$ of power at a cost of $\$ 700$ million. This is about 5 or 6 times less than the $\$ 3.4-4.6$ billion cost for the proposed $500 \mathrm{MW}$ geothermal project and accompanying undersea cable. Over the next 20 years, improved efficiency could reduce electricity demand in Hawaii by about $50 \%$ at an average cost of about $4 \mathrm{c} / \mathrm{kWh} .{ }^{38}$ The "bottom line" is that the geothermal project is risky, expensive to build and maintain, and comes with no guarantees. On the other hand, a statewide energy efficiency program, using proven technology, will free up more power than the geothermal project could ever provide, will save Hawaiian ratepayers hundreds of millions of dollars, and will buy precious time to develop other less costly renewable options such as solar and wind power.

A good analogy for Hawaii's current energy situation is a wooden tub with millions of leaks. More leaks develop every day as developers build inefficient buildings on speculation. From the utilities perspective putting in another hose and pumping in more power looks like the most obvious answer to keep the wooden tub full. However, a more intelligent and far less costly solution is to plug all of the millions and millions of leaks with reliable and readily available energy efficient technologies, and establish strong building standards to prevent more leaks from developing. If this path is followed not only will no new supply be needed over the next 10-20 years, but some of the existing supply can be turned off.

The choice is simple, improving electricity efficiency is much more cost-effective than developing any new supply options. Now that Hawaii has embarked on an integrated resources planning process this fact will be brought to light. Integrated resources planning will hopefully provide a framework to compare all available resource options, including energy efficiency improvements, on a level playing field. All available resource options must be seriously evaluated on an economic basis before plans for the geothermal project go any further.

\footnotetext{
${ }^{38}$ Estimate based on studies done in other states and energy savings in the commercial and residential sectors comparing existing technology to the most-efficient technology available for lighting, appliances, and equipment. For more detailed analysis see D. Goldstein, R. Mowris, B. Davis, K. Dolan, Initiating Least-Cost Energy Planning in California: Preliminary Methodology and Analysis, prepared for the State of California Energy and Resources Conservation and Development Commission, Docket No. 88-ER-8, February 21, 1990, available from NRDC, 90 New Montgomery St, Suite 620, San Francisco, CA 94105.
} 
Table 1. Proposed Electricity-Efficiency Measures for the Hawaii Residential Sector. Savings of 1,359 million $\mathrm{kWh}-66 \%$ of total residential demand in $1988-$ are achievable at an average cost of conserved electricity of $3.6 \mathrm{k} / \mathrm{kWh}$. Note that the statewide savings assume full replacement of the estimated existing number of units.

\begin{tabular}{|c|c|c|c|c|c|c|}
\hline Efficiency Measure & $\begin{array}{l}\text { Rebate or } \\
\text { Retail Cost } \\
\qquad \$\end{array}$ & $\begin{array}{l}\text { Annual } \\
\text { Electricity } \\
\text { Savings } \\
k W h / y r\end{array}$ & $\begin{array}{l}\text { Life } \\
\text { Years }\end{array}$ & $\begin{array}{c}\text { Cost of } \\
\text { Conserved } \\
\text { Electricity } \\
\text { c/Kwh }\end{array}$ & $\begin{array}{l}\text { Estimated } \\
\text { Number } \\
\text { Units } \\
\text { Thousands }\end{array}$ & $\begin{array}{c}\text { Statewide } \\
\text { Savings } \\
\text { Million } \\
k W h / y r\end{array}$ \\
\hline Water-Saving Showerhead 40 & 20 & 585 & 10 & 0.4 & 330 & 195 \\
\hline R-10 Water-Heater Blanket & 25 & 310 & 10 & 1.0 & $110^{41}$ & 34 \\
\hline Compact Fluorescent Lamp 42 & 12 & 88 & 6.8 & 2.4 & 1,700 & 150 \\
\hline $\begin{array}{l}1989 \text { Best Mass-Produced } \\
\text { Refrigerator-Freezer }\end{array}$ & 300 & $660^{43}$ & 20 & 3.6 & 400 & 264 \\
\hline Solar Water Heater & $2762^{44}$ & $3940^{45}$ & 30 & 4.6 & $190^{46}$ & 750 \\
\hline \multicolumn{4}{|l|}{ Average Cost of all Measures } & 3.6 & & \\
\hline \multicolumn{4}{|c|}{ Total Savings (does not include water heater blanket) } & & & 1359 \\
\hline
\end{tabular}

${ }^{39}$ The Cost of Conserved Electricity, $C C E=\left(\frac{\text { Cost of Measure }}{\text { Annual Savings }}\right) \times C R F$, where $C R F=$ Capital Recovery Factor, $\mathrm{CRF}=\frac{\mathrm{d}}{1-(1+d)^{-n}}$, where $d=$ the real discount rate (5\% for all calculations), $\mathrm{n}=$ life of investment.

40 Weighted average based on $650 \mathrm{kWh} / \mathrm{yr}$ for 230,000 4-person single-family residences and $485 \mathrm{kWh} / \mathrm{yr}$ for 150,000 3-person multi-family residences (assuming \#persons $\times 7.2 \mathrm{gal} / \mathrm{person}$-day $\times 365$ days/yr $\times 0.46 \mathrm{gal} \mathrm{hot} / \mathrm{gal}$ cold $\times 8.3 \mathrm{lb} / \mathrm{gal} \times 1 \mathrm{Btu} / \mathrm{bb}-{ }^{\circ} \mathrm{F} \times 55^{\circ} \mathrm{F}+3414 \mathrm{Btu} / \mathrm{kWh}$ ). Note that $7.2 \mathrm{gal} / \mathrm{person} / \mathrm{day}$ is the average savings for water-saving showerheads from a study of eight different water conservation programs across the United States from Residential Water Conservation Projects: Summary Report, Brown and Caldwell, Walnut Creek, Califormia, prepared for U.S. Department of Housing and Urban Development, Office of Policy Development and Research, Building Technology Division, June 1984.

${ }^{41}$ Extra insulating blankets added to all multi-family water heaters (equivalent to 110,000 units).

${ }^{42}$ Compact fluorescent lamps cost about $\$ 20$, but the marginal cost is only $\$ 12$, since they last 10,000 hours, and replace a string of thirteen $75 \mathrm{~W}$ incandescent bulbs ( 750 hour life) whose present value is $\$ 8$. The life of $6.8 \mathrm{yrs}=$ $10,000 \mathrm{hrs}+(4 \mathrm{hrs} /$ day $\times 365$ days/yr $)$.

${ }^{43}$ Savings are based on comparing the 1989 best mass-produced refrigerator-freezer that uses $840 \mathrm{kWh} / \mathrm{yr}$, to the average Hawaiian refrigerator-freezer that uses about $1500 \mathrm{kWh} / \mathrm{yr}$. Average life based on Department of Energy data. ${ }^{44}$ Retail cost of $\$ 2762=\$ 4250$ (installed cost for two $4^{\prime} \times 8^{\prime}$ panels, 120 gallon tank, pump \& controls) $-\$ 1488$ (35\% state tax credit). Source: Bill Anderson, Andersun Solar (808) 396-9288.

${ }^{45}$ Assumes base of $4800 \mathrm{kWh} / \mathrm{yr}$ (Comparative Monthly Energy Consumption \& Cost Estimtaions: 1988 Modern Single-Family Home on Oahu Family of Four, Hawaii Electric Company, Technical Services Division) minus 650 $\mathrm{kWh} / \mathrm{yr}$ for water-saving showerhead leaving $4150 \times 0.95=3940 \mathrm{kWh} / \mathrm{yr}$ savings for solar water heater.

${ }^{46}$ Assumes 40,000 units already installed with 190,000 single-family homes remaining to be retrofitted with solar. 
Table 2. Theoretical 20.Year DSM Savings and Sales Forecast for Hawaiian Utilities.

\begin{tabular}{|c|c|c|c|c|c|c|c|c|c|}
\hline & \multirow[b]{3}{*}{\begin{tabular}{|c|} 
A \\
Annual \\
DSM \\
Expenditure \\
SMillion
\end{tabular}} & \multirow[b]{3}{*}{$\begin{array}{c}B \\
\text { Retum on } \\
\text { Investment } \\
\text { (10\% RoR) } \\
\text { \$Million }\end{array}$} & \multirow[b]{3}{*}{$\begin{array}{c}C \\
\text { Taxes on } \\
\text { Return } \\
(34 \% \text { Taxes) } \\
\text { SMillion }\end{array}$} & \multirow[b]{3}{*}{$\begin{array}{c}A+B+C \\
\text { DSM } \\
\text { Expense } \\
\text { Charge } \\
\text { SMillion }\end{array}$} & \multirow[b]{3}{*}{\begin{tabular}{|c|} 
istimated \\
Stalewide \\
Sales without \\
DSM \\
(ind. 2.6\%/ys growh) \\
Million $k W h$
\end{tabular}} & \multirow[b]{3}{*}{$\begin{array}{c}\text { Estimated } \\
\text { Sales with DSM } \\
7.9 \text { TWh } 1990 \text { base } \\
\text { Reduced 0.315 TWh/yr } \\
\text { (inct. } 2.6 \% / y r \text { gromh) } \\
\text { Million } k W h\end{array}$} & & \multirow[b]{3}{*}{$\begin{array}{c}\text { Annual } \\
\text { Statewide } \\
\text { Load } \\
\text { Reduction } \\
\text { Million } k W h\end{array}$} & \multirow[b]{3}{*}{$\begin{array}{c} \\
\text { Percent } \\
\text { Load } \\
\text { Reduction } \\
\%\end{array}$} \\
\hline & & & & & & & \multirow[b]{2}{*}{$\begin{array}{c}\text { Additional } \\
\text { Average } \\
\text { Statewide } \\
\text { DSM } \\
\text { Charge Rate } \\
\text { c/kWh }\end{array}$} & & \\
\hline & & & & & & & & & \\
\hline 1991 & 75 & 7.5 & 2.6 & 85.1 & 7900 & 7585 & 0.011 & 315 & 4 \\
\hline 1992 & 75 & 7.5 & 2.6 & 85.1 & 8107 & 7477 & 0.011 & 630 & 8 \\
\hline 1993 & 75 & 7.5 & 2.6 & 85.1 & 8320 & 7375 & 0.012 & 945 & 11 \\
\hline 1994 & 75 & 7.5 & 2.6 & 85.1 & 8538 & 7278 & 0.012 & 1260 & 15 \\
\hline 1995 & 75 & 7.5 & 2.6 & 85.1 & 8762 & 7187 & 0.012 & 1575 & 18 \\
\hline 1996 & 75 & 7.5 & 2.6 & 85.1 & 8992 & 7102 & 0.012 & 1890 & 21 \\
\hline 1997 & 75 & 7.5 & 2.6 & 85.1 & 9228 & 7023 & 0.012 & 2205 & 24 \\
\hline 1998 & 75 & 7.5 & 2.6 & 85.1 & 9470 & 6950 & 0.012 & 2520 & 27 \\
\hline 1999 & 75 & 7.5 & 2.6 & 85.1 & 9719 & 6884 & 0.012 & 2835 & 29 \\
\hline 2000 & 75 & 7.5 & 2.6 & 85.1 & 9974 & 6824 & 0.012 & 3150 & 32 \\
\hline 2001 & 75 & 7.5 & 2.6 & 85.1 & 10236 & 6771 & 0.013 & 3465 & 34 \\
\hline 2002 & 75 & 7.5 & 2.6 & 85.1 & 10504 & 6724 & 0.013 & 3780 & 36 \\
\hline 2003 & 75 & 7.5 & 2.6 & 85.1 & 10780 & 6685 & 0.013 & 4095 & 38 \\
\hline 2004 & 75 & 7.5 & 2.6 & 85.1 & 11063 & 6653 & 0.013 & 4410 & 40 \\
\hline 2005 & 75 & 7.5 & 2.6 & 85.1 & 11353 & 6628 & 0.013 & 4725 & 42 \\
\hline 2006 & 75 & 7.5 & 2.6 & 85.1 & 11651 & 6611 & 0.013 & 5040 & 43 \\
\hline 2007 & 75 & 7.5 & 2.6 & 85.1 & 11957 & 6602 & 0.013 & 5355 & 45 \\
\hline 2008 & 75 & 7.5 & 2.6 & 85.1 & 12270 & 6600 & 0.013 & 5670 & 46 \\
\hline 2009 & 75 & 7.5 & 2.6 & 85.1 & 12592 & 6607 & 0.013 & 5985 & 48 \\
\hline 2010 & 75 & 7.5 & 2.6 & 85.1 & 12923 & 6623 & 0.013 & 6300 & 49 \\
\hline
\end{tabular}

Note:

1. Assumes utilities pay $4.2 \mathrm{c/kWh}$ for total savings of 6329 million $\mathrm{kWh}$-equivalent to a total one-time investment of $\$ 1.7$ billion or $\$ 85$ million/year.

2. Spending $\$ 1.7$ billion to save $6.3 \mathrm{BkWh}$ is equivalent to $\$ 1530 / \mathrm{kW}$ saved (assuming $65 \%$ capacity factor). The net savings are $\$ 3.4$ billion. 
Table 3. Estimated Cost $(\$ 1987)$ of Selected Renewable Electricity Generating Technologies. Source: Except for biomass and Ormat project, land area, lead time, and wholesale cost estimates are from the California Energy Commission (Appendix C gives spreadsheets of 30-year nominal cost data ${ }^{47}$ ).

\begin{tabular}{|c|c|c|c|c|c|}
\hline \multirow[b]{2}{*}{ Technology } & \multirow[b]{2}{*}{$\begin{array}{l}\text { Lead } \\
\text { Time } \\
\text { Years }\end{array}$} & \multirow[b]{2}{*}{$\begin{array}{c}\text { Area } \\
\text { Required } \\
\text { Acres } / 100 \mathrm{MW}\end{array}$} & \multicolumn{3}{|c|}{ 30-Year Levelized Cost } \\
\hline & & & $\begin{array}{r}\text { Wh } \\
\text { Nominal } \\
\& / K w h\end{array}$ & $\begin{array}{l}\text { lesale } \\
\text { Constant } \\
\phi / K w h\end{array}$ & $\begin{array}{c}\text { Retail } 48 \\
\text { Constant } \\
\not / k W h\end{array}$ \\
\hline $\begin{array}{l}\text { Improved Efficiency in Sugar Cane } \\
\text { Processing and Cogeneration } \\
\text { (Biomass Gasification using } \\
\text { Steam-Injected Gas Turbines) }\end{array}$ & $3-549$ & $2^{50}$ & 8.2 & $4.1^{51}$ & 7.1 \\
\hline $\begin{array}{l}\text { Solar-Thermal Parabolic Trough } \\
\text { (Hybrid with Oil-Fired Backup) }\end{array}$ & 1.5 & 500 & $10.8^{52}$ & 5.4 & 8.4 \\
\hline Geothermal (California) & 5.5 & $200^{53}$ & 12.0 & 6.0 & 9.0 \\
\hline Wind & 1.5 & $1750^{54}$ & 12.3 & 6.1 & 9.1 \\
\hline Solar Photovoltaic-Concentrating & 3 & 860 & 13.2 & 6.6 & 9.6 \\
\hline Solar Photovoltaic-Flat Plate (1995) & 3 & 800 & 15.9 & 8.0 & 11.0 \\
\hline Geothermal (Ormat $25 \mathrm{MW}$ ) & & - & 16.0 & $8.0^{55}$ & 11.0 \\
\hline $\begin{array}{l}500 \mathrm{MW} \text { Geothermal } \\
\text { Project and Undersea Cable }\end{array}$ & 10 & - & $\begin{array}{l}20 \text { Low } \\
25 \text { High }\end{array}$ & $\begin{array}{l}10.0 \\
12.5\end{array}$ & $\begin{array}{l}13.0 \\
15.5\end{array}$ \\
\hline
\end{tabular}

${ }^{47}$ Constant 30-year levelized cost estimates are about two-times lower than nominal costs, personnal communication with Gerry Bemis, Energy Technology Status Report No. 2, in preparation, CEC, 1990. ${ }^{48}$ Assuming the difference between wholesale and retail cost is about $3 \mathrm{c} / \mathrm{kWh}$. Based on U.S. average difference between retail [average of residential and commercial] and wholesale industrial prices (Table 9.9, pg. 103, Monthly Energy Review November 1989, Energy Information Administration, February 1990.

${ }^{49}$ Estimated time to demonstrate the technology is 3-5 years. Estimated construction lead-time would be about 2-3 years once the technology is commercially available.

${ }^{50}$ This estimate is based on using bagasse, a byproduct from crushing sugar cane. No extra land is required beyond existing cane processing plants except for the gasifier.

${ }^{51}$ See page 10 of Biomass-Gasifier Steam-Injected Gas Turbine Cogeneration for the Cane Sugar Industry, Eric Larson, R. Williams, J.M. Ogden, M. Hylton, presented at Energy from Biomass and Waste XIV, Lake Buena Vista, Florida, January 29-February 2, 1990.

${ }^{52}$ Nominal cost in the Mojave Desert of California is $8.7 \mathrm{k} / \mathrm{kWh}$, but more humidity in Hawaii yields less solar availablity so the adjusted nominal cost is about $10.8 \mathrm{c} / \mathrm{kWh}$ (R. McKusick and R. Topielic, NEA Analysis).

53 Not including land for piping steam from well-head to generation station, or land for waste water holding tanks.

${ }^{54} \mathrm{Land}$ underneath wind turbines can be used for grazing or agriculture.

55 Constant dollar cost from March 1990 Hawaii PUC rate case hearing awarding Ormat $6.56 \notin / \mathrm{kWh}$ on-peak, 5.43 . $\mathrm{c} / \mathrm{kWh}$ off-peak, and $\$ 4$ million/year capacity charge (capacity charge adds about $2 \mathrm{c} / \mathrm{kWh}$, assuming $90 \%$ capacity). 56 Low-assumes $500 \mathrm{MW}$ geothermal project costs are comparable to $25 \mathrm{MW}$ Ormat project plus the undersea cable add-on cost of $2 ₫ / \mathrm{kWh}$. High-based on Economic Analysis of the Kilauea Geothermal Development and Inter-Island Cable Project, R. McKusick, R. Topielic, Northwest Economic Associates, assuming 30\% contingency. 


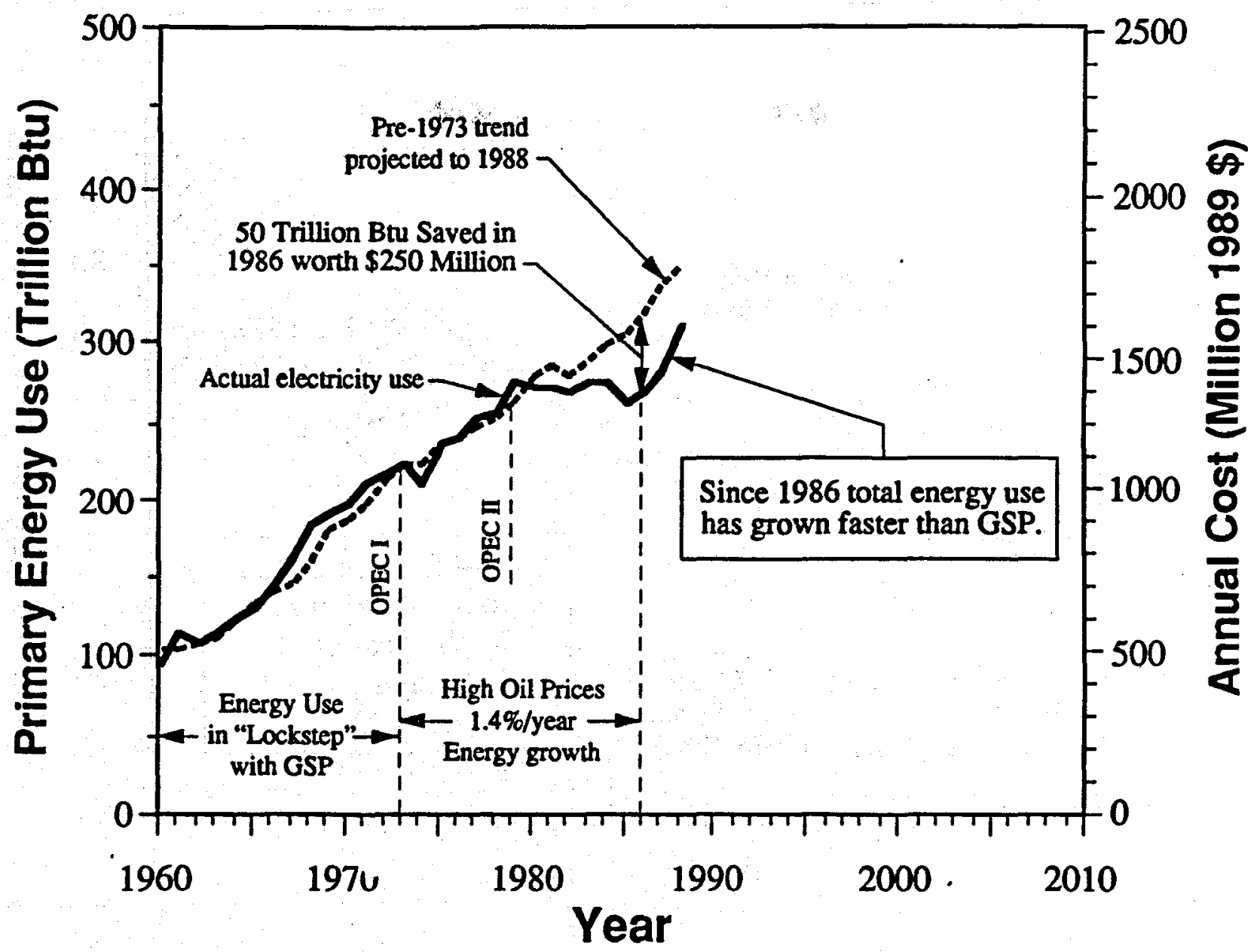

Figure 1. Hawaii Energy Use: Actual and Projected by Gross State Product (GSP). Before the first oil crisis in 1973 (OPEC I), energy use was in lockstep with GSP. From 1973 to 1986 high oil prices limited energy growth to only $1.4 \%$ /year while GSP rose 3\%/year. Compared to pre-1973 efficiency levels, Hawaii saved about 50 trillion Btu in 1986 equivalent to 8.5 million barrels of oil worth $\$ 250$ million. After oil prices collapsed in late 1985, Hawaii temporarily lost its focus on energy efficiency, and total energy use is currently growing faster than GSP.

Sources: Energy use-State Resources Coordinator Annual Report, July 1987 to June 1988, Hawaii Department of Business and Economic Development, Honolulu, HII. Projections based on 1988 energy use and GSP. All GSP data are from the Hawaii Department of Commerce and Consumer Affairs. 


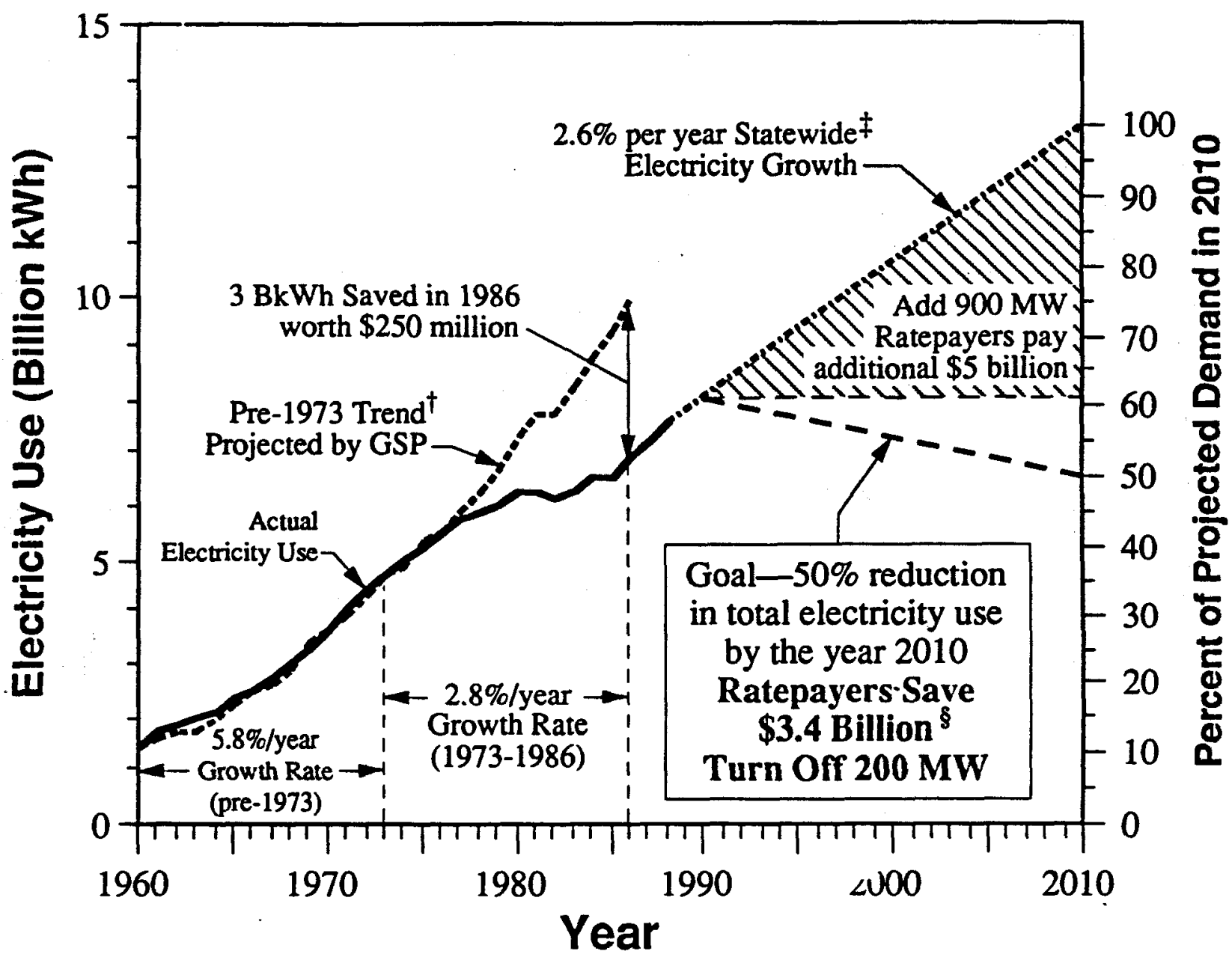

Figure 2. Hawaii Electricity Use: Actual and Predicted by Gross State Product (GSP). Hawaii's goal over the next 20 years should be to reduce electricity use by $50 \%$, equivalent to an annual efficiency improvement of 3.4\%/year. Improving statewide electricity efficiency by $50 \%$ will cut demand from 13 to about $6.5 \mathrm{BkWh}$ in 2010, and save Hawaiian ratepayers $\$ 3.4$ billion. If electricity use continues to grow $2.6 \%$ /year over the next 20 years Hawaiian utilities will need to build an additional $900 \mathrm{MW}$ of capacity and the ratepayers will have to spend an additional $\$ 5$ billion. Achieving a 50\% reduction in total statewide electricity use will require the combined efforts of the Public Utilities Commission, utilities, legislators, manufacturers of energy using technologies, builders, developers, and the general public.

tThe pre-1973 trend is Electricity $=$ Electricity $_{1973}\left(\frac{\text { GSP }_{t}}{\operatorname{GSP}_{1973}}\right)_{(1.028)^{(t-1973)}}$

¥The 1990-2010 trend is based on projected electricity growth of 2.5\%/year (1990-2000) and 2\%/year (2000-2010) for Oahu, and 3\%/year (1990-2000) and 2.5\%/year (2000-2010) for the other islands [personal comunication Alan Lloyd, Hawaii Electric Company, May 4, 1990].

\$Assuming $1000 \mathrm{MW}$ produces $5.7 \mathrm{BkWh} / \mathrm{year}$, an average price of $9.4 \mathrm{c} / \mathrm{kWh}$, and an average cost of saved electricity of 3.5 $\$ / \mathrm{kWh}+20 \%$ for program costs or about $4.2 \mathrm{eWWh}$. Net savings per $\mathrm{kWh}$ are $9.4-4.2=5.2 \mathrm{k} / \mathrm{kWh}$, and total net savings are the total area between the two extremes-i.e. $65 \mathrm{BkWh} \times 5.2 \mathrm{ckWh}=\$ 3.4$ billion. The extra spending is the shaded area of $53 \mathrm{BkWh} \times 9.4 \mathrm{~d} / \mathrm{kWh}=\$ 5$ billion.

Sources: Electricity Uso-State Resources Coordinator Annual Report, July, 1987 to June 30, 1988, Hawaii Department of Business and Economic Development, Honolulu. HI. All GSP data are from the Hawaii Department of Commerce and Consumer Affairs. 


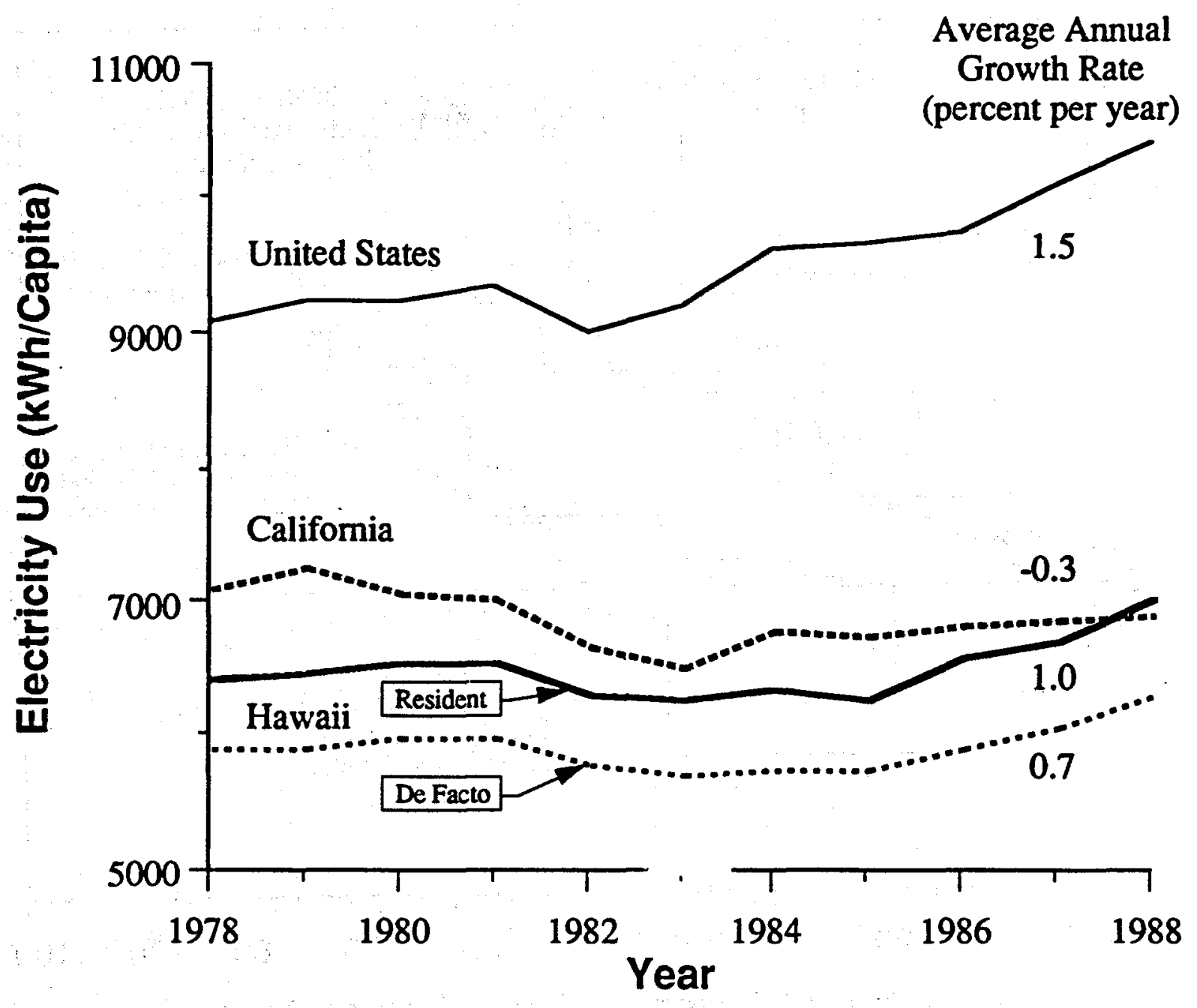

Figure 3. Per Capita Electricity Use in Hawaii, California, and the United States, 1978-1988. California's building and appliance standards and utility incentive programs have significantly reduced per capita electricity use over the past decade. In 1988 the average Californian used $210 \mathrm{kWh}$ less than in 1978, while in 1988 the average Hawaiian used 580 $\mathrm{kWh}$ more than in 1978. Including Hawaii's visitor population, defacto per capita electricity use over the ten year period increased by $415 \mathrm{kWh}$. The population of both states increased by about $20 \%$ over the ten year period (tourism added $2.4 \%$ to Hawaii's de facto population growth).

Source: Electricity data-Electric Power Annual, DOE/EIA-0348(87), and DOE/EIA-0348(82), U.S. DepL. of Energy, Energy Information Agency. Population data-Statistical Abstract of the United States, 1989 ed., U.S. Dept. of Commerce, Statistical Abstract of California, and Hawaii Dept. of Commerce and Consumer Affairs. 


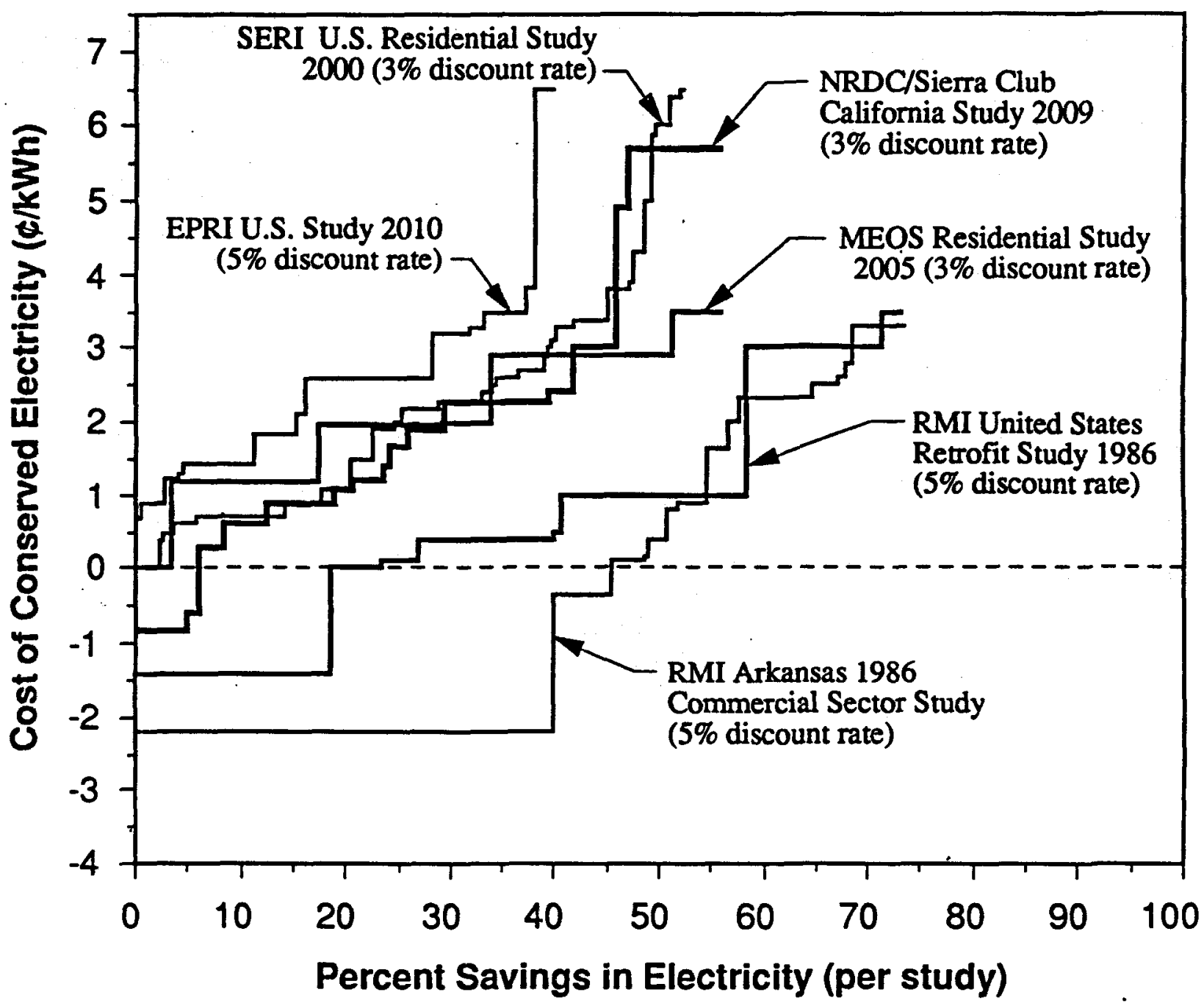

Figure 4. A Collection of Efficiency Supply Curves Indicating the Technical Potential for Electricity Savings in the United States. These curves imply that for an average cost of less than $2 \mathrm{~d} / \mathrm{kWh}$ it is technically possible to save $40-75 \%$ of annual electricity use within the United States. The Electric Power Research Institute (EPRI) study examined all sectors of the U.S. in the year 2010. The Natural Resources Defense Council/Sierra Club study examined commercial lighting and residential lighting and appliances in California in year 2009. The MEOS study examined residential lighting and appliances. The Solar Energy Research Institute study examined all sectors of the U.S. in the year 2000, but only the residential electricity efficiency supply curve is reproduced here. Rocky Mountain Institute examined retrofitting the entire U.S. and the Arkansas commercial sector using 1986 as a base year.

Source: Efficient Electricity Use: Estimates of Maximum Energy Savings, prepared by Barakat \& Chamberlin, Inc., EPRI CU-6746, March 1990 (and personal communication A. Rosenfeld with A. Faruqui, Barakat \& Chamberlin, Inc.). Initiating Least-Cost Planning in California: Preliminary Methodology and Analysis, D. Goldstein, R. Mowris, B. Davis, K. Dolan, Natural Resources Defense Council and The Sierra Club, prepared for the California Energy Commission, Docket No. 88-ER-8, February 1990, A New Prosperity, Building a Sustainable Future, The Solar Energy Research Instinute (SERI) Solar/Conservation Study, Brick House Publishing, Andover MA, 1981, and Competitek, A. B. Lovins, R. Sardinsky, P. Kieman, T. Flanigan, B. Bancroft, M. Shepard, Rocky Mountain Institute (RMI), 1986, Analysis of Michigan's Demand-Side Electricity Resources in the Residential Sector, F. Krause, A. Rosenfeld, M. Levine et al, Lawrence Berkeley Laboratory, LBL-23026, 1987. 


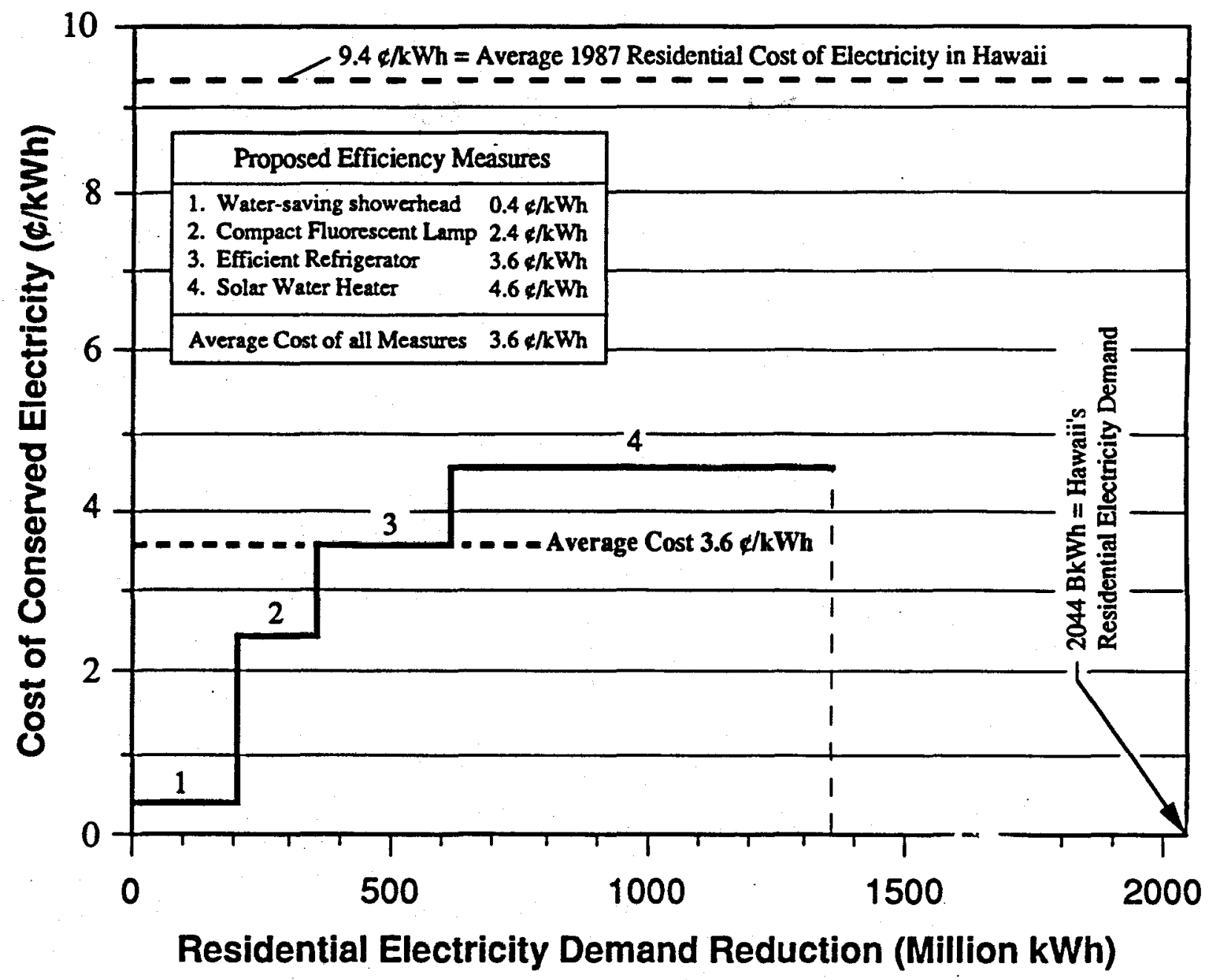

Figure 5. Residential Electricity-Efficiency Supply Curve for Hawaii. If Hawaii invested in a statewide efficiency program, total residential electricity demand could be reduced by $66 \%$, at an average cost of $3.6 \mathrm{c} / \mathrm{kWh}$, saving 1,359 million $\mathrm{kWh}$. The average cost to Hawaiian ratepayers is about 4 times less than the proposed geothermal project and accompanying undersea cable.

Note: A 5\% real discount rate was used for the analysis. The marginal retail cost of each efficiency measure was used to calculate the cost of conserved energy. For more detail see Table 1. 


\section{APPENDIX A}

\section{Power By Design:}

The New England Electric System Energy Efficiency Plan

Excerpted from NEES Will Spend \$65 Million A Year On Conservation, by Susan Lincoln, p. 4, The Energy Daily, Tuesday, November 7, 1989. 


\section{NEES Will Spend \$65 Million A Year On Conservation}

\author{
BY SUSAN LINCOLN
}

New England Electric System. the second largest utility in the six-state region. is embarking on a \$65 million per year search for a new source of energy. Oil has not been discovered in Boston harbor, nor coal in Vermont, but NEES hopes to find megawatts in New England's homes, businesses, and factories.

NEES will be investing its millions in energy-efficient light bulbs, air conditioning, electric motors and building design, according to the Westborough, Massachusettsbased utility. Another $\$ 500$ million will be spent in New England for energy efficiency measures over the next three years.

$A$ twist in the venture is a partnership with the Conservation Law Foundation, an environmental group traditionally at loggerheads with energy utilities. CLF and NEES are collaborating in the new program called "Power by Design," which aims to ease the region's increasingly tight electricity supply and avoid building new power plants by tapping into energy efficiency.

While CLF portrays the program as "a stroke of genius" and takes much of the credit for spurring the utility to action, energy efficiency has been a company priority "well before CLF entered the picture" said a NEES spokesman. NEESPLAN, the utility's overall strategic plan has included reducing electricity use through conservation and efficiency since 1979, according to NEES president John Rowe.

Douglas Foy, executive director of CLF, dubbed the project the "third generation" of energy conservation. The first was the hardship model, turning down thermostats, foregoing electric blankets and wearing sweaters, Foy said. The second generation was efforts to get consumers to buy energy efficient appliances by offering rebates, performing energy audits and similar incentive programs.

Yet these programs never seemed to take off. The missing piece was a clear profit motive for the electricity supplier, the utility. Without the ability for the utility to earn a return on the investment, Foy explained, conservation measures were doomed to remain good public relations, without serious impact on utilities' projections of future energy needs and their plans for new facilities.

Enter CLF. The group co-authored a report in 1987 titled Power to Spare. The report concluded that New England could meet between 35 percent and 57 percent of its total electricity needs for the next twenty years through currently available ef ficiency improvements, while maintaining or increasing the region's current rate of economic growth. The energy supplied through efficiency would cost between one-quarter and one-half the price of kilowatts supplied from new power plants.

Lack of utility action or investment was identified as a key obstacle to consideration of conservation. Power 10 Spare concluded that energy eificiency is a resource that should be purchased like any other resource, not left to customers to finance.
The crucial difference, Foy says, is to switch the utilities from a goal of selling kilowatt hours to selling energy services. It's a return to the ideas of Thomas Edison, Foy pointed out. The inventor's original company sold light, not kilowatt hours. If those services can be provided to the consumer for less kilowatts, no one loses-neither the consumer nor the utility - and the environment gains in avoiding the need for new plants. Utilities also avoid the risky and resource-consuming task of trying to build new capacity.

So in 1988 CLF took their case to four of the utilities commissions in the New England region and won converts. With "various degrees of coercion" state regulatory commissions in the area ordered the utilities to put conservation on a "level playing field" with new power generation, said CLF staff attorney Stephen Burrington.

First to get off the ground was NEES. The Massachusetts Department of Public Utilities ordered the utility company to work with former adversary CLF to design and implement state-of-the-art energy efficiency programs. Since such large scale direct investment in energy efficiency by utilities is unprecedented. the jointlydesigned program was to include rigorous monitoring and evaluation provisions, open to revamping as experience grows.

Now the "Power by Design" plan is set to launch, and has already begun by retrofitting low-income houses in Worcester, Massachusetts. The first year of the plan sets a goal of 60,000 homes and 15 million square feet of office space to retrofit and redesign. NEES will spend over $\$ 65$ million this year alone.

The program blazes some new ground in utility-sponsored energy efficiency programs, according to CLF's Burrington. First is the scale of the project, and the direct utility involvement, rather than indirect consumer incentives programs. "It represents the first attempt by $a$ utility to really go after energy efficiency," said Burrington.

NEES will pay for the additional expense of designing an energy-efficient heating and cooling system for new buildings. For existing buildings, the utility will replace regular light bulbs with energy-efficient bulbs which use one quarter of the electricity and last ten times as Tong as incandescent bulbs-all at no cost to the homeowner or business.

Second is a more complex, but crucial bookkeeping change. Previously, utilities wrote off investments in energy conservation as expenses. The cost of conservation investments were applied for that year only, providing a lower rate of return than investments in new generation that were ratebased, or subject to long-term amortization.

NEES has worked out a cost-recovery deal with the utility commissions where conservation investments can be included in the ratebase, earning interest on the investment equal to capital sunk in new generating capacity. As an additional carrot, the ratesetters are allowing an extra return to be earned by the utility.

Although ratebasing efficiency measures has been tried before, for example in Wisconsin, the New England case is different because the cost-recovery plan is tailored to encourage cost-effective energy efficiency measures, according to Burrington. In addition, the utility commission has agreed to let the price per kilowatt to rise, making up for the potential overall decrease in demand.

Susan Lincoin is a reporter for Environment Week, a sister publication to The Enargy Daily. 


\section{APPENDIX B}

\section{A Model Least-Cost Electrical Policy}

Excerpted from A Brighter Future: State Actions In Least-Cost Electrical Planning, by Lisa Shapiro, Paul Markowitz, Nancy Hirsh, The Energy Conservation Coalition, A Project of Environmental Action Foundation, 1525 New Hampshire Avenue, N.W., Washington, DC 20036 (202) $745-4874$ 


\section{A Model Least-Cost Electrical Policy}

This trad. planning evaluation and enforcement. provide a framework for evaluating how well your state is ensuring utility investments in least-cost electroal resources.

\section{A PLANNING. EACH UTILTY SUBMITS A LEAST-COST RESOURCE PLAN}

Planning requirements ensure that utilities have identified all avalable options for meeting new electncal demand before makung large expenditures.

\section{Are your utilities required to file long-range resource plass?}

Each utility should be required to submit a long-range (ten or twenty years) resource plan every one or two years to the state regulatory commission. Comprehensive utility plans should include all of the following components: 2

a Forecast of Future Demand Utilities should file forecasts of future electrical demand which identify two-to-three possible ccenarios for demand growth to help account for the large degree of uncertainty regarding future energy consumption. Demand forecasts should utilize a combination of the follow. ing forecast meth. ' '....s:

End-use analysis: This methodology calculates the number. type and efficiency of electrical end-uses leg water heaters. lighting industrial molors) in each customer class. It incorporates the impacts of changes in efficient technologies. appliance saturation levets. and utility sponsored conservation programs.

Econometric analysis: This methodology examines the impact of economic changes (e.g increases in personal income. population growth. price increases in alternative fuels) upon electracity consumption

b. Assessment of Supply side Resource Options: Utility plans should specify how the utility intends to meet future demand through vanous supply-side options. including renewable energy resources leg wind. solar. geothermal. hydro power. biomass). cogeneration. power purchased from other utilities. and traditional sources such as coal and nuclear power.

c. Assessment of Demand Side Resource Options: Utility plans should document that utilities are making every effort to achieve the full potential for cost effective conservation and load management investments. Plans should document not onIv the costeffective potential for these imvestments. but also specify planned and proposed programs which are designed to achieve this potential. Utility conservation programs should go bevond educational efforts and energy audit programs to include financial incentives. such as low-interest loans. cash rebates. and third-pany financing, designed to stimulate customer conservatuon investments. a Integration of Supply and Demand Side Resource Op. rions: The cornerstone of a least-cost plan is a side-by-side evaluation of the relative cost-effectiveness of all supply and demand-side resource options. The plan should detail the resource mix of those investments that will provide eiectrical service at the least possible cost. A separate least-cost mix should be developed for each demand growth scenario.

c. Two Year Implementation Plar: Each utility should sub. mit a separate two year plan that specifies how it will imple. ment its long-range resource plan. This implementation plan should specify exactly which resources the utility expects to acquire in the upcoming two-year period.

f. Plan Summary. The plan should include a non-technical summary of the utility's projected load forecast and proposed resource options for meeting load to help facilitate public participation.

\section{B. EVALUATION: STATE REVIEWS UTILITY PLANS}

State evaluation of utility resource plans tand other utility filings) is essential to assess whether utilities have adequately fulfilled their filing requirements and have adequately examined alternative supply and demand-side options.

Has your regulatory commision extablished specific guidelines for utility plans and other filings?

The state regulatory commission should set guidelines that specify what information is required and which methodologies should be used by utilities in preparing their resource plans. These guidelines should use state-of-the-art approaches. and assure consistency among utility plans and systematic review by all interested parties. For example. the commission should establish specific regulatory criteria and develop a standard set of methodologies to evaluate the cost. effectiveness of utility conservation programs. ${ }^{3}$

\section{Has your state developed a state-wide electrical energy plan?}

An independent state energy plan should be developed and updated every two years. This plan should follow the same guidelines established for the preparation of utility plans and he a standard against which to evaluate utility plans. This plan can be conducted by the commission itself. another state agency (e.g. state energy office). or an independent research institution (e.g state university). A comprehensive state plan should contain scenarios of future eleetrical demand. assessments of altemative supply and demand-side resource options. and an analysis of various policy options which can be implemented to achieve a least-cost stratcqu. 
Does vour Commission have special provisions for public participation in the resource planning process?

The commission should hold open hearings to review and examine proposed utility resource plans. Public involvement in the review process is necessary $10: 11$ inform the public and iegitumize the process. 2) ensure consideration of all potential resource options and the consideration of all poten :1al impacts of utility plans: 3) ensure commission and utility sccountability: and 4) enhance public acceptance.

The least-cost plannine process should also include oppor. tunities for informal review sessions among consumer groups. the business community. local energy researchers and individual citizens as the plans are developed. This will help utulities incorporate a wide range of input into their resource plans.

Funding mechanisms should be developed to ensure the establishment of public representation in the utility planning process. plant licensing and/or ratemaking proceedings. For instance. ciuzen utility boards (CLBs) are funded through toluntary contributions from ratepayers through access to utulity bills. ${ }^{6}$ On the other hand. a state utility consumer adwucate is often funded through a surcharge on utility bills.'

\section{E.NFORCEMENT: EFFECTIVE CONTROL OVER UTILITY INVESTMENTS}

The commission should have sufficient reguiatory powers Junng the plannine, powerplant ticensing and ratemaking processes to effectively ensure utility investments in least-cost resources.

\section{Does your commission have the authority to approve or disaf. 'tilities' long-range resource plans?}

Your commission should have the authority to reject utility resource plans that do not satisfy established regulatory quidelines and require utılities to revise inadequate plans." These guidelines can be procedural in nature. t.e requiring utilities to mcet specific information requirements. and/or can be substantıve. 1.4. requiring utlities to devise specific proirams or meet specific conservation goals. State authority to upprove or disapprove utilitv resource plans should bc strongly tied to its ability to evaluate the utility load forceasts and resource asscssments.

Une of the most crucial elemenis of a comprehensive lcastcost planning process is the requirement that all utility in. iestments be consistent with utility resource plans. Siates with this csscntial provision are able to use utility resouree plans for their opiumal functions: as a benchmark on how the utility proposes to meet future electrical demand before the investments have been made.

Does your sate require a certificate of public need before authorizing the siting or contruction of new power plants?

States should exercise control over the siting and/or construction of new power plants by requiring a certificate of need toften referred to as a certificate of public convenience and necessity) in which the utility must establish the need for the power plant. A certificate of need should only be issued wher:
1. The plant is in compliance with the utility's resource plan: Permits for new plants should only be considered if the plant is consistent with the utilitvs most recently approved resource plan. This ensures integration and consistency of utility investments with the utility planning process."

2. The need for the plant has been firmly established Ltility demand forecasts should be scrutınized in light of state-conducted forecasts. for compliance with state specifications. and to account for any changes which may have occurred since the resource plan was filed. ${ }^{10}$

3. The plant is the least-cost means of meeting the need: Utilities should be required to demonstrate that the proposed plant is the least-cost option in light of all available demand-side and supply-side options.

further. the commission should have the authurity to review the ceruficate of need every two years in light of any changes in the utility's approved resource plan with the burden of proof resting on the utilities. Again. state authority to require a certificate of need should be strongly tied to its ability to evaluate proposed utility power plants in light of least-cost altematives. Further. the commission should still mantain the Juthonty to disallow imprudent costs from the rate base.

Has vour commission used its ratemaking powers to encourage utility least-cost investments?

Ratemaking authority is important as a final check to ensure least-cost investments. but is most effective when used in conjunction with comprehensive planning and plant licensing processes. Proposed rate increases should be evaluated in the context of the uulity's most recently approved resource plan. and rate recovery should be allowed only for those investments which have been included in the plan. Further. the commission should develop regulatory guidelines for what constitutes used and useful investments to assure that uneconomic utility expen. ditures are disallowed from the rate base.

\section{Does your commission have authority to require utility conservation programs?}

Your commission should have regulatory authority to require utilities to offer financial incentives designed to stumulate customer investments in energy conservation. such as low-interest loans or cash rebates. While most commissions are granted specific statutory authority to require these investments. many commissions have relied on broad regulatory powers to ensure adcquate and reasonable supplies of electricity" as the legal basis for requiring conserva. tion investments."

A few state commissions offer utilities financial incentives and/or impose financial penalties to encourage conservation investments. For instance. some commissions provide revenue guarantees to utilities for innovative or untested resource in. vestments (e.p pilot conservation programs). Other commissions are moving toward performance based financial incentives whereby utllitics are rewarded or penalized according to their progress in achieving certain efficiency goals. rather than a stnct rate-of-return on total assets. In this manner, commissions can reward or pcnalize a utility bascd upon progress toward achicving conservation goals or implementing its resource plan.12 
Has your commiscion set avoided cost rates which require utilities to purchase electricity from small-power producers?

The Public Litilities Regulatory Policies Act (PURPA) of 1978 (Title I of the National Energy Act) requires electric utilities to purchase electricity from small-power (renewable energy and cogeneration/ producers at a price equal to the utility's cost of producing electricity. Your commission should establish rates that reflect the long-term cost of building new power plants. This will maximize the development of alternative resources. while assunng lower rates for all ratepayers.

\section{REFERENCES}

1. Markowiz Paul and Joseph Kriesbers Least-Cost Elecmoal Planning is There Really a State Moument. Critical Mass Energy Project 215 Pennsylvania Ave.. SE Washington. DC 33.50 (December 1985).

2. For example. see 704 Nevada Administratuve Code. Sections 900955 (Oct 1984). Contact the Nevada Public Service Commission. 505 East King St. Carson City. NV 89710.

3. For example. see 25 Florida Statutes Annotated. Section 17 (1985). Contact the Florida Public Service Commission. 101 East Gaines St. Tallahassee. FL 32301.

4. For example. see lllinois Statutes Annotated. Section $8-402$ (h) (1985). Contact the Illinois Commerce Commission. 527 East Capitol Ave.. Springfield. IL 62706.

5. Northwest Electric Power Plannin, and Conservation Act. Public Law 96-50. Section 4 (g) (1) (1980). Contact the Northwest Power Planning Council. Suite 1100.850 S.W. Broadway, Portland. OR 97205.

6. For more information. contact the Citizen Utility Board Organizing Project. 215 Pennsylvania Ave. SE Washington. DC 20003 (202-546.9707)

7. For more information contact the National Association of State Utility Consumer Advocates. 1424 16th St. NW. Suite 105. Washington, DC 20036.

8. For example. see 196 Wisconsin Statutes. Section 491 (2) (1975). Contact the Wisconsin Public Service Commission. P.O. Box 7854. Madison. WI 53707.

9. For example. see 704 Nevada Administrative Code. Section 890 (Oct 1984). See address above.

10. For example, see Texas Substanuve Rules. Aricle VII. Section 54(eX1) Uuly. 1985). Contact the Texas Public Utilities Commission. 7800 Shoal Creek Blud. Austin. TX 78757.

11. For example. see New York Public Service Commission. Opinion \#8415. Case 28223 (May 21. 1984). Contact the New York PSC. Empire State Plaza Albany. NY 12223.

12. For example. see 66 Kansas Statutes Annolated. Section 117 (a) (1985): and 366 Florida Stantes Annotated. Secvion 82(4) (1980). Contact the Kansas Corporation Commission. State Office Building. Topeka KS 66612. 


\section{APPENDIX C}

\section{Detailed Cost Data . Renewable Electricity Generation Technologies}

Excerpted from State of California Energy Resources Conservation and Development Commission, Final Report: Technology Characterizations, prepared for the 1990 Electricity Report (ER 90), Docket No. 88-ER-8, Gerald R. Bemis, Arthur J. Soinski, Samuel Rashkin, Alec Jenkins, Roger L. Johnson, California Energy Commission, and Michael Radovich, Ebasco Environmental, October 1989. 


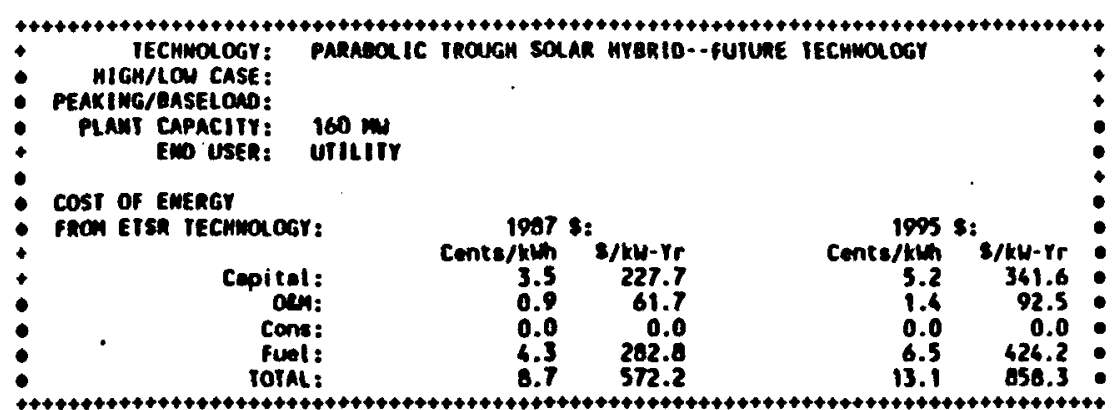

(c) Copyrighe 1906, 1907 Polytme, Inc. All righte Reeerved

Plant capital cost:

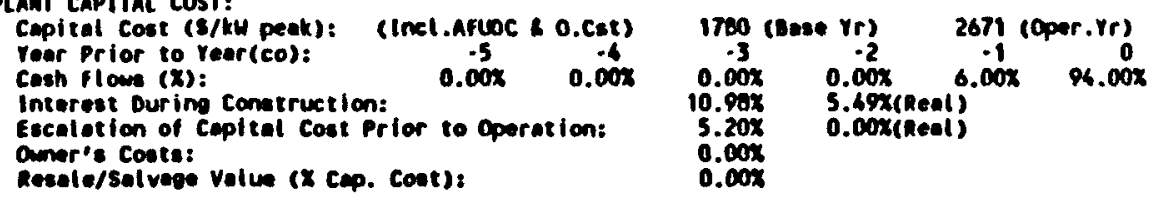

PLaMt operatsou parnaetens:

Year Comisercial Operutlion:

Plant Cepecity Fector
plimt life (reers):

OPERAIIMG PARManeteRs (Bose Year s):

operating \& Ma intenence coete (oin): Pixed $(s / k w-Y r):$
voriable (nills/km):

$\underset{30}{1905} \quad 6570 \mathrm{Hrs}$

\subsection{0 (Buse Year)}

Consumables Cost (sa/tb):

Consumables Rote (tb/tumi:

Fuel costs (f) (s/matu):

Heat Rote (HR) (Btw/hh)

Thormal Energy Rote (notw/k(n)):

soler frection

2.70 (Base Year)

$33.49 x \quad 2200$ wrs

ECOMONIC PARAMEIERS:

onse vear (Doltars):

Inflution note:
Investment Period (rears):
fLAGS:

Exclude (1) va. Include (0) Interest Iax Shelter

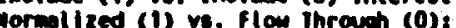

Flmaucial paraneters (Aftor Incom rex):

cosi of CAPJIAL (DISCOUNI FACTOR)

Cost of Common Equity (ke):

Cost of Preferred stock (kp):

Percent Common Equity (C/V):
Percent Preferred stock (P/V):

Percent Preferred stock (P/N)

Coet of Copitel:

I Cost of Capital

deat coverage:

Coverege Ratio:

fiXed CMARCE RATE:

$$
\text { ica }
$$

IAX PARAME TERS:

Marginal fedorel income tox Rate (I):

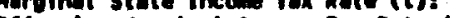

Eifective Morginal Income Inx hate (f')

other

Feder In

Fecteral Enerey Tou credit (FEIC):

state Enerey tax Credit (seic):

\section{Depreciation:}

Federel: waces-os

Stete:

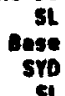

Bese
Capital Deprecistion sese:
in-service month (1...12):

PLANT Capital cosi (s/kw):

Overnight construction cost:

Overnight construct

ESCALATIOO RAIES:

Avolded Energy cost (En):

Avolided Capecity Cost (EC):

Avolided Thermal Energy (Et):

operating 2 maintenence (EO)

Consumables (Eg):

Copitel Construction (EC):
$12.7400 \quad 7.17 x$ (ranl)

$9.290 x \quad 3.09 x(r e a 1)$
$9.290 x$
$3.09 x($ reol)

$49.00 x$

$6.00 x$
$45.00 x$

10.90x $5.49 \times($ real)

$C=\quad 3.58$

$0.120 \quad 0.072$ (reat)

34.000
9.300

6. oox (effectives

$6 . \operatorname{cox}(010)$
$1.16 x$

$0.00 x$

$0.00 x$

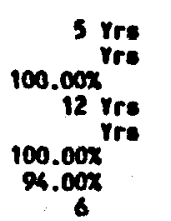

1995 s:
2671

Actual: Real:

$0.00 x \quad-4.04 x$

$0.00 x \quad-4.94 x$

$6.25 x \quad 1.008$

$\begin{array}{rr}0.00 x & -4.96 x \\ 7.03 x & 2.50 x\end{array}$ 


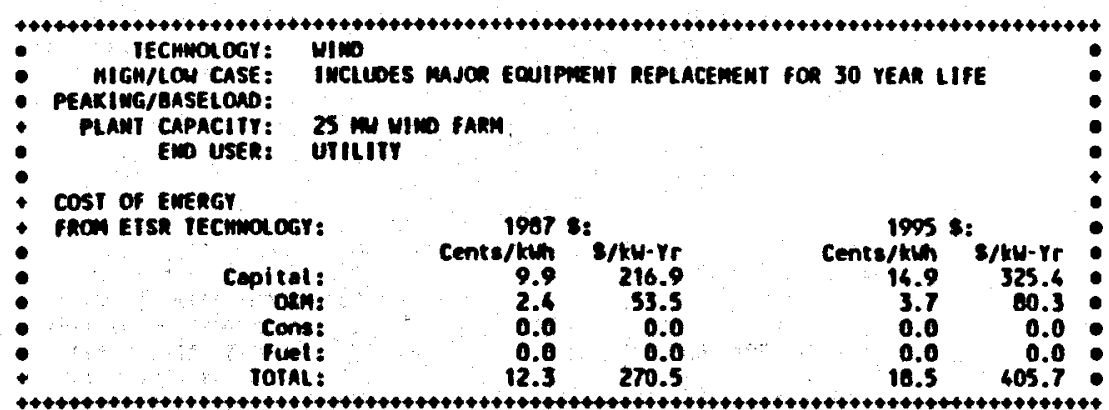

(c) Copyright 1906, 1987 polythe, Inc. All rights Reserved
PLAMT CAPIIAL Cost:

rear prior to reor

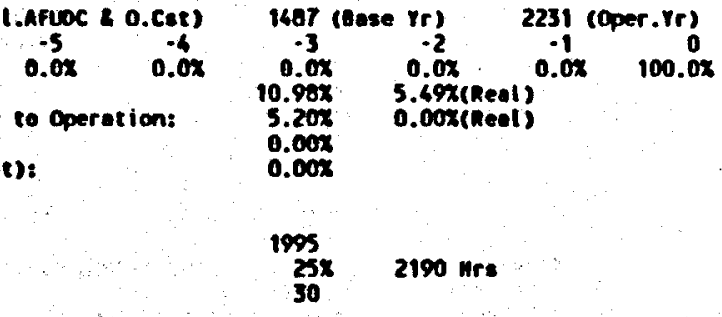

Interest Ouring Construction: amer's Costs:

Reenle/selvege volue (x cep. cont)

PLANT OPERaIIOU parumeters:

Yeer Comenercisl operotion:

plent Cepocity fector

$25 x=2190$ Mrs

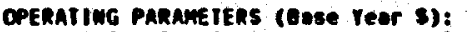

Qperatione Mointenence Costs (Cey):

Fined (senu-yri

veribble (mills/k(n)):

12.00 (Base Year)

Consumables cost (se/Lb):

Consumables Rote (Lb/kum)

Fuel coste (f) (S)raru):

Thermal Eneroy Rete (nesu/km)

solor fraction:

(Bose Year)

0.008

0 Mrs

ECOMOMIC PARnMETERS:

Oase Year (Dollars):

Imvestment Period (reers)
fLAGS:

Exclude (11) ve. Include (0) interest iox shelters

(i) ve. Flow inrough (0):

fimancial parameiers (After Incom tax):

cosi of CAPital (DIScouml factoo)

cose of cowmon Equity (ke):

cost of Preferred stock (kp):

Percent Comon Equity (C/V):

Percent Preferred Stock (P/V):

finencina (O/v):

cost of cepitel:

ofar coverace:

Coverepe Rotio:

FIXED CMARCE RATE:

fCe

ron:

cost of Copital

TAX PARAmETERS:

Marginat federal Incame lax Rote (I):

Marginol Stete Income lax Rate (t):

Effective Warginal Incam

redoral Inmotwent rox cr

stese Enerey ion Credit (seIC)

DEPAECIATION:

Pederol: Macrs-on

SL
onse
STD
SL
Stoste:

Capital Depreciotion oase:

In-service month (1..12):

PLAMT CAPITAL COSI (s/ku): Overniont construction cose: lotel Plent cost:

1987 s: 1603
1407

Escalation Rates:

Avoided Eneroy Cost (EA):

Avolded capactiy cost (EC):

aperatiog a Mainterence (EO):

Consuneble (ED):

fuel (Ef):

Copitel Construction (EC):
$12.7600 \quad 7.17 x$ (reel)

9.2900 3.09x(reat)

$49.00 x$

$6.00 x$

$10.90 x \quad 5.49 \times($ real)

$C R=3.7$

$0.166 \cdots 0.089$ (reel)

36.000

60.148

6.00x(etfoctive)

$1.14 x$

$0.00 x$

$15 \mathrm{Yre}$
$100.00 \mathrm{Yre}^{\mathrm{rre}}$
$20 \mathrm{Yrs}$
$100.00 \mathrm{Yr}^{\mathrm{r}}$
$95.00 \mathrm{x}$

.000

1995 :

Actual: Reel:

$0.000 \quad-4.94 x$

$0.00 x \quad-6.94 x$

$5.20 x \quad 0.00 x$
$0.00 x \quad-4.96 x$

$0.00 x-4.96 x$ 


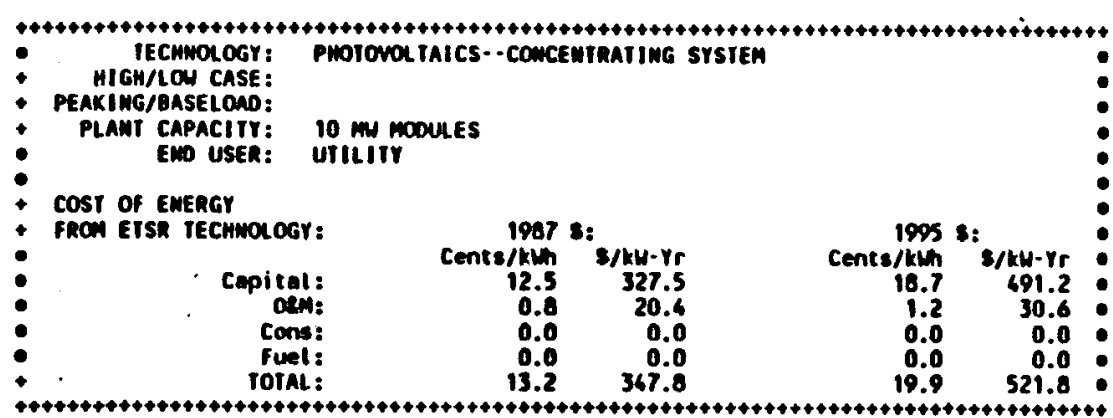

(c) Coppright 1986, 1987 Polyotme, Inc. All rights heserved
FLAGS:

shetrer:

Hormollized (i). Include (0) Interest

fimancial paraneiers (After income lex)

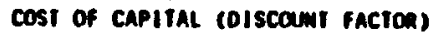

Cost of Compon Equilty (ke):

cost of Debe finencing (tod):

Percent Common Equity (C/V):

Percent Preferred Stock (P/V):

cost of capitat:

- rom

I cost of capital

1 Accounting

DEAT COVERAGE:

Coverage Rot io:

fixeo charge aATE:

$$
\text { fea }
$$

12.760x 7.17x(real)

.2900 3.09x(real)

$49.00 x$

6.000
45.000

$10.90 \times$

$5.49 x($ real)

PLAMI CAPIJAL COST:

Year Prior to Year(co): (Inct.afloc \& 0. cat)

$\begin{array}{cccc}2250 \text { (Bose } \mathrm{Yr} \text { ) } & 3376 \text { (Oper.7r) } \\ -3 & -2 & -1 & 0 \\ 0.08 & 0.0 x & 20.0 x & 00.08\end{array}$

Entereat During Construction:

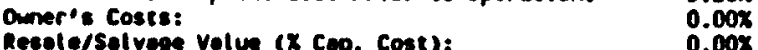

Plami operallom parameters:

Year comperciel operation:

Plont cepecity fector (CF)

$\underset{30}{1995} 2626$ Wre

Operatiug paremeters (Bose Year 8 ):

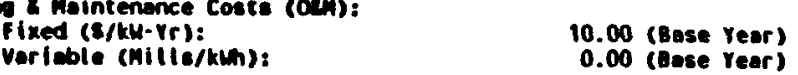

Consumeter cost (seshbs)

es Rote (Lb/kLm)

Fuel costs (f) (s/metu):

Went hote (HR) (Btw/kth):

soler frection:

2.70 (Base Year)

$0.00 x$

D Mre

ECOMOHIC PARMMETERS:

Dose Year (Dollers):

Investmont period (vears):
1907

30

\section{TAX PARAMETERS:}

Marginal stote Income Iax Rote (t):

Effective Marginal Income Tax lote (Ti)

stute Soles Iox Rote (ts):

other Toxes (Property) (to):

Federst investment Tou credit (IIC):

Fodoral Eneroy Iex Credit (FEIC)

\section{DEPRECIATIOW:}

Federal: macks-do

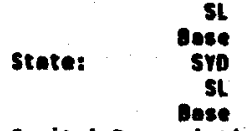

Copital Deprecietion base:

in-service month $(1, .12)$ :

PLAMT Caplital cosI (s/kW): Overnight construction cost:

Oet Ptant Cost:

ESCALATION RATES:

Avoided Energy cost (En):

Avoided Capecity cost (EC):

aperating 1 maintenence

Consumablies (Eg):

fuel (EF):

copitel Conseruction (Ec)

1987

2250
Marginal federal Income Iax Rote (I):
CR $=\quad 3.72$

0.1660 .089 (reet)

$34.00 x$

$40.14 x$

6.00x(effective)

$1.14 x$

$0.00 x$

$0.00 x$

15 Tre

20 Yrs

$100.00 x^{\text {Vr }}$

$9.00 x$
6

1995 s:

Actual: Real:

$0.00 x-6.96 x$

$0.004 \quad-4.94 x$

$0.25 x \quad 1.000$

$\begin{array}{ll}0.00 x & -6.94 x \\ 7.03 x & 2.50 x\end{array}$
$0.00 x-4.94 x$ 


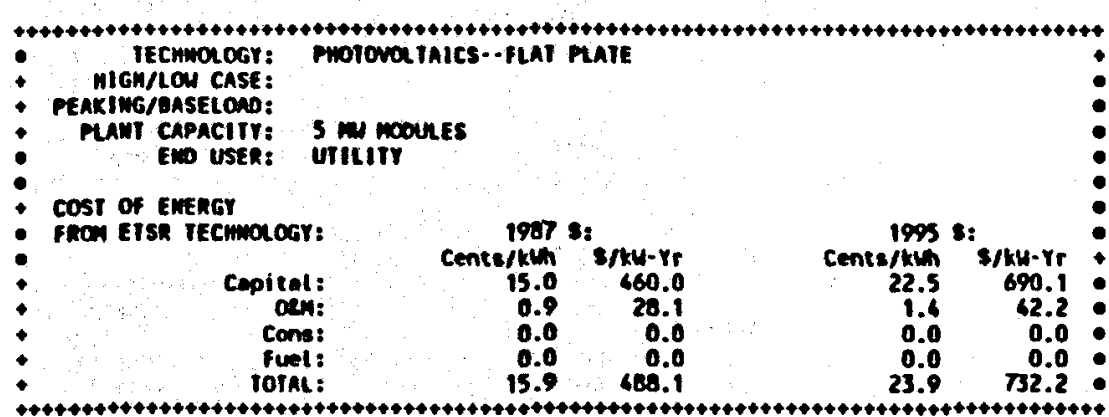

(c) Copyright 1966, 1987 polyotme. Ine. All riahts Reserved

PLAMT CAPITAL COSI:

Copital Cost (S/ku peat): (Incl.afuoc a o.cos)

$\begin{array}{lcc}\text { Year Prior to Year(co): } & -5 & 0.4 \\ \text { Cosh fious (X): } & 0.0 x & 0.0 x\end{array}$

Cash flows (X):

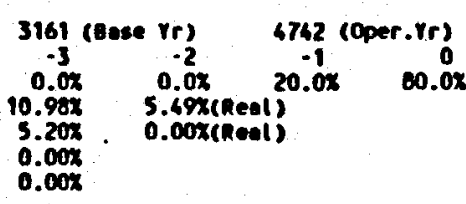

Escaletion of cepitel cost prior to operation amer' coste:

Roeste/solvepe valive (x cap. Cost):

${ }_{30}^{1995} 3006$ Hrs

Year Commerciel Operation:

Plent life (rears):

Inas:

(1) vs. Flow inrough (0)

fimanciat parnesteas (after incom tex):

cosi of CAPIIAL (oIScoumi PACton)

Cost of Comon Equity (ke):

cost of Preferred stock (kp):
cost of Debe Pinencing (kd):

Percent Common Equity (C/V):

Percent Preferred srock (P/V):

cost of Copitol:

ras:

cost of cepitel

DEet coverace

Coveroge Rntio:

FIXeo charce anie:

$12.740 x \quad 7.17 x($ real)

$9.290 x$ 3.89x(real)

$49.00 x$

6.000

$10.90 \times$

S.49\%(real)

\section{IAX parametens:}

Morginel federal Income tox Rase (I):

Werginal state Income Iox Rete (t):

Effective Marginal Income lex kete (I I):

stote Soles Tax hote (tr):

Oiher raxes (Property) (to):

Federal inveatment Tox credit (ITC)

Federst Eneror Tox credic (fEIC):

CPEAHIng paknietens (base year s):

Deperetim o mointenence cost cotin).

$$
\begin{aligned}
& \text { Pixed (s/kw-Yr): } \\
& \text { Verioble (nills/kun): }
\end{aligned}
$$

13.00 (Gose rear)
0.00 (Gase Vear)

Consumeblea Cost (s0/Lb):

Consumables Rate (Lb/kth):

Fuel Costs (F) (\$/Matu):

Thereml Energy Rate (notu/kun):

solar frection:

2.70 (eose rear)

$0.00 x$

O Mrs

ECONONIC PARRMETERS:

Dese rear (Dollors):

Imvestent Period (rears) $\underset{30}{19.207}$

\section{DEPRECIATIOW:}

Federel: macns-de

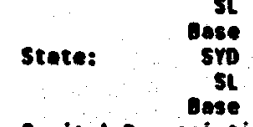

Capiral Depreciotion Bnse:

PLAMT Capitul cosi (s/ku):

Overnight construction cost:

plent cost:

ESCALAIIOM RatES:

Avoided Energy Cost (En):

avoided capacity cost (EC):

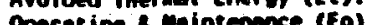

Conscumables (Eg):

fuel (Ef):

Capital Construction (EC):
$C R=3 . n$

0.1660 .009 (real)

$34.00 x$

40.16

6.00x(offective)

$1.14 x$

$0.00 x$

0.000

$$
\begin{aligned}
& 15 \text { Yre } \\
& \text { Yre } \\
& 100.00 x \text { Yre } \\
& 28 \text { Yre } \\
& 100.000 \\
& 0000
\end{aligned}
$$

$9.00 x$

$\begin{array}{cc}1995 \text { 8: } & \\ 6762 & \\ & \\ \text { Actwol: } & \text { Real: } \\ 0.00 x & -4.96 x \\ 0.00 x & -4.94 x \\ 0.00 x & -4.96 x \\ 6.25 x & 1.00 x \\ 0.00 x & -4.94 x \\ 7.03 x & 2.50 x \\ 5.20 x & 0.00 x\end{array}$




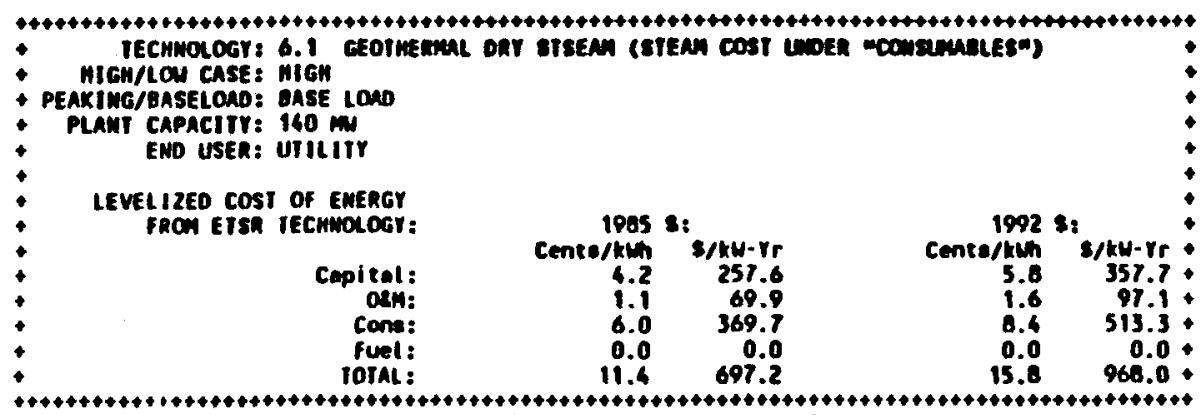

(C) Copyright 1986, 1907 Pol yotyre. Inc. All hights Reserved

PLAMT CAPIIAL COSI:

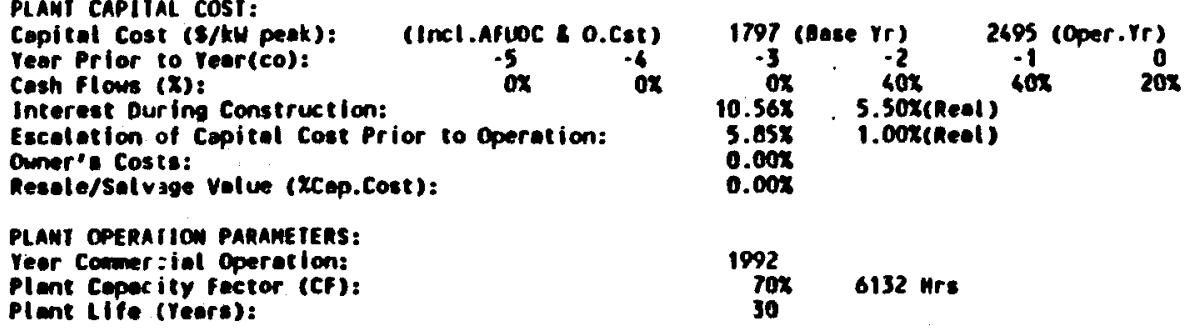

CPERAIING ParameIERS (Bose veor \$):

ce costs (oun):

$$
\begin{aligned}
& \text { fined (s/kw. Yr): } \\
& \text { vorioble (Hills/kth) }
\end{aligned}
$$

Consumebles cost (sB/fb):

Consimables Rate (Lb/kth):

fuel Costs (F) (S/Matu):

Heot Rote (HA) (orw/km):

Solar fraction:

OrMER cosis:

Insurence Rate (b)

Minencing Cost (n) of Capital investments

nemegement fees $(x$ of Grose Opereting inco

ECONOMIC PARAMEIERS:

Base vear (Dollers):

Infintion Rate:
Investment Period (rears):

14.56 (8nse Year)

3.31 (Qese veer

0.017

(base rear)

$0.00 x$ urs

$0.00 x$

$0.00 x$

$\underset{30}{1985}$

RUM DAIE: $13 \cdot$ Sep-80 flags:

cofore-ten (1) vi. After-tex (0):

I cont of copital

financial paranerers:

cosi of CAPIIAL (DIScoumi incion)

cost of Compon Equilty (ke):

coot of Proferred stock (kp):

Percent Comon Eguity (C/ $V)$ :

Percent Debt ffinemelong (o/v)

Cost of Capitni

Dear coverace:

Coverage nat lo:

fIXEO CMARGE RATE:

$$
\text { FCR }
$$

\section{IAX PARAME IERS:}

Merginal Fectersl income lax Rete (1):

Morginel stote Incane Ion Rote (t):

Effective Moroinal income tex Rote (I')

stete soles lon hote (to):

Pederal Imvestuent Iox Credit (IIC):

federal Eneroy Iox credie (fetC):

state Energy tax credit (stic):

\section{oepaeciailiom:}

federel: Mucrs-da

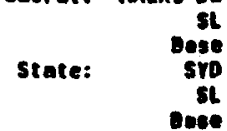

Copital Depreciotion onse:

In-service month (1..12):

PLAMT CAplital cosi (s/kw):

Overnight Construction cost:

Dose Year:
1500

1500

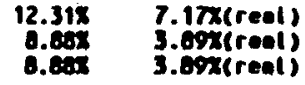

45.004

$10.5675 .50 x($ real)

CR $=3.81$

0.1430 .091 (real)

36. $90 x$

6. 0ox(effective)

6.002
$1.14 x$
$0.00 x$

$0.00 x$

$0.00 x$

ESCALAIIOW RATES:

Avolded treray cost (EA):

Avolded copocity cost (EC):

Avolded thermat Emarer (Ets:

Operat ing \& Mointenence (EO)

Consunobles (Eg):

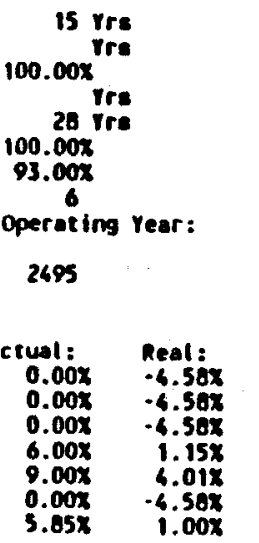




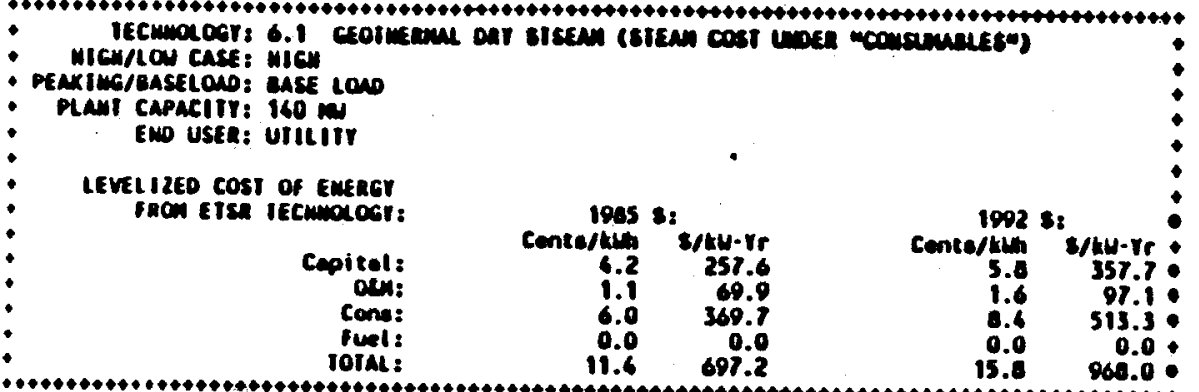

(C) Copyr lght 1906, 1907 Pol votme, inc. All alchts Reserved

\section{plani capital cost:}

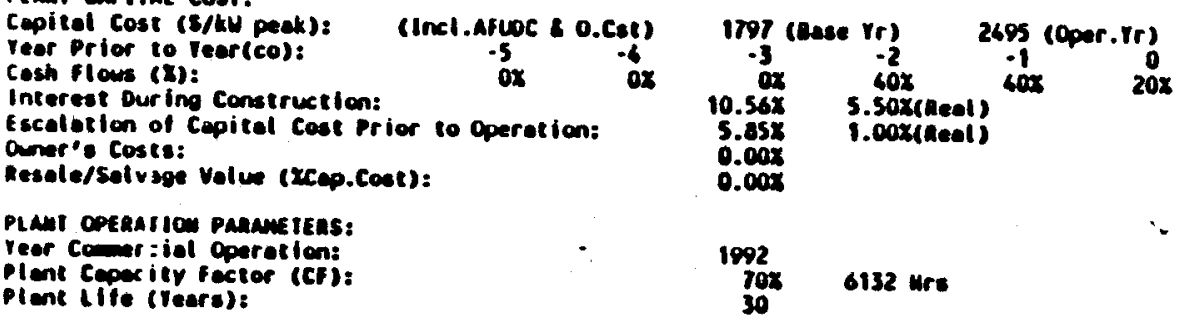

coenaling r mancitas (Base veer s):

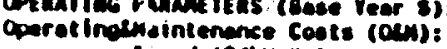

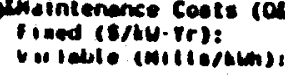

cunsumebles Cost (8s/tb):

Consumebles Rete (lb/k(ti)

luel coots (f) (s/mitu):

inerool Eneror hote (motu/kin):

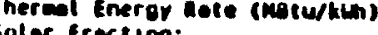

OIMER COSIS:

linsur ance Aste (b):

inencing Cost ( $x$ of Capitel Imvestent):

${ }_{30} 6132$ Mre

Aanagement lees ( 2 of Grose Operet ing income)

I COMONIC PARame Iens:

Gose rear (Dollors:

investment period (rears):

16.56 (1000e rear)

0.017

(Oase vear)

$0.00 x \quad 0$ urs

$0.00 x$

$0.00 x$
$0.00 x$

1085

$60 x$
30 tlacs:

Cofore-tex (1) ve. aller-tan (0)

Fimuacial pauncteas:

cost of Capital (DIscowi racion)

cont of comon Equily (ke):

cont of proloring stoc

(t):

Percent Common Equilty (C/W):

Percent Preferred stock (P/V):

Percent Detbt finencion (O/v):

Cost of Cepitot:

DEOI COVERAGE:

Coverege hat lo:

fIXED Cunace maIe:$$
\text { fCR }
$$

IAX PARaMe IEas:

Morginal Federal Income Iox lote (I):

Merginal stote incem lax tote (t)s

Elfective Morginel Incoms lax ate (I'):

Stete seleb ton hate (to):

foder ol imeetiment Iol (redit (IIC):

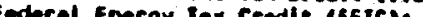

state Eneroy ian crodis (seicis

OEPRECIAtIon:

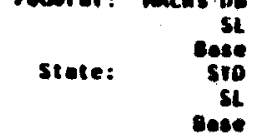

Capital Depreciotion tase:

In-service month (1..12):

plani capilial cosi (s/atu)

Overnight construction Cost:

lotal Pient Cost:

ease rear:

1500
1707

ESCALAIION RAIES:

Avolded Eneroy Cout (EO):

Avolded cepoct cost (EO):

Avolded therael Eneroy (EE):

Oper ot ing 4 mointenence (EO)

Consumbles (Eg):

Copital Construction (tc):
Cost of Cepitel

12.31x 7.17z(real)

e.ex J.evureals

$49.00 x$

$6.00 x$
$45.00 x$

$10.56 x \quad 3.50 x(r e a l)$

$\mathrm{Ca}=3 . \mathrm{al}$

0.1630 .091 (reol)

$3.00 x$

$3.00 x$
$9.30 x$
$6.14 x$

$6.00 x$ (elfective)

$1.16 x$

$0.00 x$

$0 . \infty 00 x$

is vi:

$100.00 x$

20 Ire

$100.00 x$

6

2485

$\begin{array}{cc}\text { actuol: } & \text { neal: } \\ 0.00 x & -6.50 x \\ 0.00 x & -6.58 x \\ 0.00 x & -6.58 x \\ 6.00 x & 1.15 x \\ 9.00 x & 6.01 x \\ 0.00 x & -6.50 x \\ 5.05 x & 1.00 x\end{array}$

